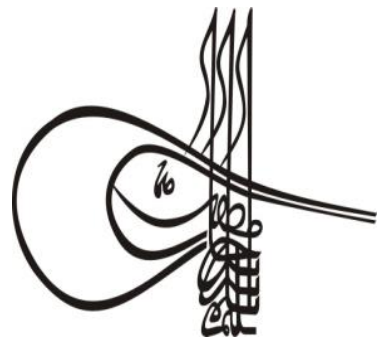

Received/Geliş: 22.02 .2019

\section{Turkigh Studies Educational Sciences}

Volume 14 Issue 3, 2019, p. 773-799

DOI: 10.29228/TurkishStudies.22754

ISSN: 2667-5609

Skopje/MACEDONIA-Ankara/TURKEY

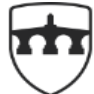

INTERNATIONAL BALKAN UNIVERSITY

EXCELLENCE FOR THE FUTUR IBU.EDU.MK

Research Article / Araştırma Makalesi

Article Info/Makale Bilgisi

This article was checked by iThenticate.

\title{
EĞİTIMDE KULLANILAN ÖDÜL CEZA UYGULAMALARININ, ÖĞRETMEN GÖRÜŞLERİNE GÖRE ÖĞRENCİLERİN DUYUŞSAL ALANLARI AÇISINDAN DEĞERLENDİRİLMESI
}

\author{
Ali ÖZDEMIR* - Ayşe YILMAZ ${ }^{* *}$
}

\begin{abstract}
ÖZ
Öğretmenlerin sınıflarında en çok başvurdukları yöntemlerden birisi ödül ceza uygulamalarıdır. Öğretmenler ödül ceza uygulamalarını; öğrencilerin ders başarılarını artırması, öğrencilere istendik davranışları kazandırması, sınıf içi düzen ve disiplin sağlaması gibi farklı amaçlarla kullanmaktadirlar.

$\mathrm{Bu}$ çalışmanın amac1, öğretmen görüşlerine göre, sınıfta kullanılan ödül ve ceza uygulamalarının öğrencilerin duyuşsal alanları açısından değerlendirilmesidir. Çalışmada, nitel araştırma yöntemlerinden biri olan durum çalışması deseni kullanılmıştır. Çalışma grubunda İstanbul İl Milli Eğitim Müdürlüğü' ne bağlı olarak görev yapan, kıdem y1lı 2 ile 20 yıl arasında değişen; 4 okul öncesi öğretmeni, 4 sınıf öğretmeni ve 3 PDR uzmanı olmak üzere 11 katılımc1 yer almaktadır. Çalışma grubu amaçlı örnekleme yöntemlerinden biri olan ölçüt örnekleme tekniği kullanılarak belirlenmiştir. Çalışmada yarı yapılandırılmış görüşme tekniği kullanılmış, görüşme sonucunda elde edilen veriler betimsel analiz tekniği ile analiz edilmiştir. Araştırmadan elde edilen bulgulara göre; katılımcı öğretmenler sınıfta ödül ve ceza uygulamalarını, kendilerinin uygun gördükleri ölçütlere göre kullanmaktadırlar. Öğretmenler ödül ve cezayı kullanırken planlananın dışında beklenmedik sorunlarla karşılaşmaktadırlar. Sınıflarda kullanılan ödül ve ceza uygulamaları, genellikle bireye yönelik olmayıp sınıftaki tüm öğrencilerin aynı beklentiyi karşılamasına yönelik olmaktadır. Sınıflarda bu şekilde tüm öğrencilerin aynı beklentiye göre ödüllendirildiği veya cezalandırıldığı durumlar; sınıf içinde ödül alan,
\end{abstract}

Dr. Öğr. Üyesi, Marmara Üniversitesi, E-posta: aliozdmr32@gmail.com

İlköğretim Matematik Öğretmeni, Milli Eğitim Bakanlığı, E-posta: ayseyilmaz4432@gmail.com 
ödül alamayan ve ceza alan öğrenci boyutlarıyla değerlendirildiğinde fark edilmeyen sıkıntıların oluşmasına yol açmaktadır. Çalışma sonucunda ödül ceza uygulamalarının istendik davranış kazandırmadaki bazı olumlu etkileri görülmüştür. Bu olumlu etkilerin daha çok duyuşsal alan özelliklerinin ilk aşaması olan merak uyandırma, motivasyon sağlama yönünde olduğu görülmüş, bununla birlikte bunları sağlarken bazı istenmeyen değerlerin ortaya çıkmasına sebep olduğu da görülmüsstür. Çalışma kapsamında ele alınan merak uyandırma, motivasyon sağlama ile başlayan duyuşsal alan özellikleri, ileri aşamalarda tutum geliştirme, değer oluşturma, öz denetim sağlama şeklinde uzun vadede kalıcı olması beklenen ve içselleştirilmeye ihtiyaç duyulan kazanımlardır. Bulgular sonucunda sınıflarda kullanılan ödül ceza uygulamalarının bu konuda yetersiz kaldığı hatta yanlış kullanım durumlarında uzun vadede kalıcı zararlar oluşturabileceği düşünülmektedir. Öğretmenler ödül ve ceza uygulamaları yerine farklı çalışmaların öğrencilerde daha uzun vadede kalıcılığı sağlayacağını düşünmektedirler. Bunlardan başlıcaları "örnek olma, farklı öğretim yöntem tekniklerini kullanma ve somut yaşantılar sunma" şeklindedir. Çalışma sonucunda elde edilen bulgular doğrultusunda öğretmenlere, araştırmacılara ve yetkili birimlere önerilerde bulunulmuştur.

Anahtar Kelimeler: Ödül-ceza uygulamaları, duyuşsal alan, istendik davranış, pekiştireç

\title{
ASSESSMENT OF REWARD-PUNISHMENT PRACTICES USED IN EDUCATION IN TERMS OF STUDENTS' AFFECTIVE DOMAINS ACCORDING TO THE TEACHERS' OPINIONS
}

\begin{abstract}
One of the methods that teachers use most in their classrooms is reward-punishment practices in order to increase the students' course success, to gain students desired behaviors, and to provide classroom organization and discipline.

The aim of this study is to evaluate the reward and punishment practices used in the classroom in terms of affective domains of students according to the teachers' opinions. This study is conducted based on a case study method, which is a qualitative research method. The study group is to consist of 11 teachers working in the schools under the Istanbul Provincial Directorate of National Education, who are 4 preschool teachers, 4 (primary school) classroom teachers and 3 Psychological Counseling and Guidance experts. Their teaching experience varies between 2 and 20 years. Participants were selected by using the criterion sampling method, one of the purposive sampling methods. It was used semi-structured interview technique in the study. The data obtained from the interviews were analyzed by using descriptive analysis technique. According to the findings obtained from the research, participant teachers are to use reward-punishment practices in the class according to their own criteria. Teachers face unexpected problems outside of the plan while using the reward and punishment. The reward punishment practices used in the classrooms are generally not for an individual but they are for meeting the same
\end{abstract}

Turkish Studies - Educational Sciences

Volume 14 Issue 3, 2019 
expectation from all students in the classroom. In this way, the situations in which all students are rewarded or punished according to the same expectation lead to problems that are not recognized when they are evaluated in terms of the students who receive rewards in the class, who cannot receive rewards and are punished. As a result of the study, it is seen that reward punishment practices have some positive effects on the formation of desired behaviors. It has been seen that these positive effects are mostly related to arousing the curiosity and providing the motivation which is the first stage of the affective domain features. However, it has also been seen that some undesirable values may occur while providing them. In the scope of the study, affective domain features starting with arousing curiosity and providing motivation are the objectives which are needed to be internalized and expected to be permanent in the long term, in the shape of attitude development, creating value, providing self-control in the advanced stages. As a result of the findings, it is thought that the rewardpunishment practices used in the classrooms are insufficient in this regard and even may cause permanent damages in the long-term in case of misuse. Teachers think that different applications instead of reward and punishment practices will provide longer-term persistence in students. The main ones of them are "setting a good example, using different teaching method-techniques and presenting experiences". Based on the findings obtained, it has been made suggestions to teachers, researchers and authorities.

\section{STRUCTURED ABSTRACT}

\section{Introduction}

One of the methods that teachers use most in their classrooms is reward-punishment practices in order to increase the students' course success, to gain students desired behaviors, and to provide classroom organization and discipline.

Reward and punishment is one of the most used methods in the field of education. According to the behavioral approach, it is thought that operant conditioning which is effective on animals (rewardpunishment practices in education) will be effective in raising children too (Cüceloğlu, 2015).

The concept of educating the ideal people with education has required to set "Educational Objectives". Educators stated that the human qualities which are specified as "objectives" can be classified according to certain criteria. In the $1950 \mathrm{~s}$, Bloom et al. have made a purpose classification which will be helpful for the answer to the question "What kind of changes will occur in the student at the end of the teaching process?. This classification consists of three basic domains: cognitive, affective and psychomotor domains (Çelik, 2006).

Bloom (1956) has stated in his book "The Taxonomy of Educational Objectives "that the affective domain is the development of interests, attitudes, values and appreciation. New terms have been added to the affective domain structure expressed as interests, attitudes and values in the beginning by working on it and by looking at the definitions of concepts. 
The affective domain consists of two main parts. The first part consists of the elements of the taxonomy that explain the nature of the affective domain: interests, attitudes, values, judgments. The second part consists of five categories explaining the acquisition stages of affective objectives and arranged hierarchically. This hierarchy is 1 . Receiving Phenomena, 2. Responding to Phenomena, 3. Valuing, 4. Organization, 5. Characterization (it means internalizing values) (Krathwohl, Bloom ve Masia, 1964).

There is no doubt that reinforcement in learning is necessary according to most learning theories. However, the same reinforcement may not have the same effect on each student, and may even have the opposite effect. The fact that reinforcement options are in a limited number in terms of their varieties and quantities means that some students cannot be reinforced correctly. Besides, it would not be right that a teacher expects to be motivated by the same reinforcement from the whole students (Bloom, 2016). Although the fundamentals were based on different assumptions, both the behavioral approach (Smith et al., 2015) and other approaches (Bloom, 2016; Wadsworth, 2015) emphasized the correct use of reward and punishment to get the desired result. The manner of reward/punishment use, the frequency and the amount of it, the duration of it, the time of it, the state of the appropriateness of a person or persons used reward/punishment, the balanced use, etc. can be said that the factors are in the expression of "the correct use".

Acquisition of affective domain features is a process being longterm, needing a lot of effort, starting with awareness and desired to become increasingly permanent. In this process, teachers take an important role in terms of having face-to-face communication with the student (Gable, 1986; Gömleksiz ve Kan, 2012). For this reason, it is necessary to understand how and in what aspects the reward and punishment practices that teachers use according to the criteria they consider appropriate affect the affective domain characteristics of students. It is thought that evaluating of the reward and punishment practices used in education addressed in this study in terms of the dimensions of creating desired value and self-control required throughout the life, motivation towards learning, being interested, developing a positive attitude towards the course and the school will make a significant contribution to the literature.

The problem situation of this study has been determined as "What are the views of teachers about the evaluation of reward and punishment practices used in education in terms of affective domains of students?".

\section{The Aim and the Significance of the Study}

The aim of this study is to evaluate the reward and punishment practices used in the classroom in terms of affective domains of students according to the teachers' opinions. Accordingly, this study aimed to answer the following questions:

1. How and in what manner are the reward punishment practices in class life?

Turkish Studies - Educational Sciences

Volume 14 Issue 3, 2019 
2. What and how are the views of teachers about the difficulties of reward punishment practices?

3. What and how are the perceptions of teachers about affective domain and reward punishment practices?

4. What and how are the desired and unexpected (undesired) consequences of reward punishment practices in terms of the affective domain according to the teachers' opinions?

\section{Method}

\section{Research Design}

This study is conducted based on a case study method, which is a qualitative research method. Case study is to analyse one or more cases thoroughly. The purpose of the analysis is to reveal conclusions about specific situations. The case study is a research method that is based on "how, why, and what?" and enables to investigate a phenomenon or a case thoroughly in a research (Patton, 2016). In this research, the case study aims to understand deeply how the reward-punishment practices used in education are in terms of the affective domains of the students, according to teachers' experiences.

\section{Study Group}

The study group is to consist of 11 teachers working in the schools under the Istanbul Provincial Directorate of National Education, who are 4 preschool teachers, 4 (primary school) classroom teachers and 3 Psychological Counseling and Guidance experts. There are 5 male and 6 female teachers in the study group, whose teaching experience varies between 2 and 20 years. Participants were selected by using the criterion sampling method, one of the purposive sampling methods.

\section{Data Collection Tool}

The data were obtained through semi-structured interview form by using semi-structured interview technique. In a semi-structured interview, the researcher prepares the interview form which includes the questions that he/she has planned to ask before, besides, the researcher may continue to interview by asking different or subquestions depending on the flow of the interview (Karasar, 2008). This is a technique that gives flexibility to the researcher in terms of getting more detailed information, asking some questions at the same time or changing the places of some questions depending on the situation (Yıldırım ve Şimşek, 2011).

In the preparation of the semi-structured interview form developed by the researchers for collecting the qualitative data of the study, the views of two field experts are received their opinions and then the questions have been formed with basic questions at the end.

\section{Data Analysis}

The data obtained from the interviews were analyzed using descriptive analysis technique which is one of the qualitative data analysis methods. The descriptions obtained by being based on the research questions asked within the scope of the sub-objectives were coded and the categories determined. The data obtained within the related sub-objectives were presented according to the determined 
categories. Then, these categories and descriptions were interpreted and the results of the research were reached. In the study, direct quotations were included to reflect the views of individuals too. The descriptions being similar were included representatively in the findings, but the interpretation, conclusion and discussion were made by taking into consideration all the answers.

\section{Findings and Interpretation}

It is seen that participant teachers use the reward in the shape of tangible, symbolic and social rewards. Also, it is seen that the types of punishment used by the participant teachers are of two broad types: (Type 1 punishment) assigning an additional duty and giving verbal warning, and (Type 2 punishment) deprivation of activities, break time, etc.. It is seen that one teacher doesn't prefer the reward and punishment use.

When Table 2 is examined, it is seen that the participant teachers stated the reward and punishment use within the scope of three situations. Teachers are to use the reward and punishment according to the percentage of the students' participation in lessons, their success and mainly their behaviors.

It was observed that the participant teachers stated their reward and punishment use within the sope of 4 criteria. According to the table, the teachers are to use reward according to the status of being provided the criteria set by them, according to the status of setting a good example of a student, according to the status of participation in the activity and according to the status of getting ahead in the ranking (such as doing something first or doing something the most, or having the highest rank). According to the table, some teachers seem to have especially avoided using the ranking status criterion.

When Table 4 is examined, it is seen that the teachers express the problems they face in 7 dimensions while using reward and punishment. These dimensions are differences in perceptions about the same practice, difficulties in following up, being experienced inconsistencies, that the reward becomes the goal by going beyond the desired objective, reinforcing the undesired behavior unintentionally, being needed the continuous feedback because of addicting to reward and stereotyped views.

The participant teachers stated that the use of balanced reward would contribute positively to the development of motivation and positive attitude. According to the table, the participant teachers stated that the punishment given appropriately would contribute positively to the self-control dimension. The participant teachers (in the environment given a reward) stated that getting a punishment and not being able to receive a reward successively in the environment given reward affects motivation negatively and it causes loss of interest and curiosity. They stated that they could lead to negative attitude development due to falling motivation and interest. According to the table, it is seen that the participant teachers stated that not balancedly used the rewardpunishment practices damages students' self-control and causes the formation of undesired values in students. 
The majority of the participant teachers stated that the values would not be gained with reward-punishment. They have expressed an opinion that values can be gained better by using different ways such as setting an example to the student, using different teaching methodtechniques in the classroom and presenting experiences instead of the reward-punishment practices. On the other hand, a participant has expressed an opinion that the behaviors could reach the value dimension in the long term with the balanced and careful use of the reward.

Yllmaz (2018) found in his research that acquisition of value might be through different ways. Fidan (2009), in his research related to the views of prospective teachers, inferred that setting a good example can be the most outstanding factor for the value teaching. Güven (2017) found that game-based experiences increased the formation of desired behaviors. Türküm (1998) stated in his research that experiencing and showing experiences about nature would be much more permanent in order to create value towards nature, instead of using external stimuli such as reward-punishment. In Gündoğdu (2007)'s research and Sadık (2008)'s research, even if it is seen the use of reward and punishment is effective in providing the desired behavior, the effectiveness here is in the dimension of classroom management discussions. Considering that the formation of value is that an individual's external controls give way to internal control in time and showing the will in practicing the value (Krathwohl, Bloom and Masia, 1964), (controlled) external practices such as reward-punishment will help to some extent to gain certain behaviors, but it cannot be said that they make an individual acquire permanently a value, that is to say, it means not to reach the value dimension. The findings of this study are in parallel with the related research results and the literature review.

In related researches, it is inferred the fact that rewarding significantly increases motivation (Cameron and Pierce, 1994), that an inappropriate reward for a person does not motivate that person (Corr, 2002), that uncontrolled use of reward has a negative effect on intrinsic motivation in the long term (Aypay, 2018), that tangible rewards and rewards being dependent on a condition generally have a negative effect on intrinsic motivation (Cameron and Pierce, 1994). Also, in the studies about the fact that the punishment partially increased motivation (Turhan and Yavaş, 2013), it has been reached the findings that Type 2 punishments such as deprivation of activities, saying words being unkind greatly harms the motivation (Pehlivan, Köseoğlu ve Şen, 2018; Sürücü and Ünal, 2018).

In these researches about the effect of reward and punishment on motivation and in the literature, it is seen that the reward and punishment use increases motivation in general; but there are various findings and information that uncontrolled and inappropriate rewards harm the internal dimension of motivation.

In this study, the findings obtained by the teachers such as "Reward and (according to situation) punishment increase motivation." and "If the reward becomes the aim, the reward rather than information will arouse students' curiosity and it will reveal undesired behaviors like jealousy." are to show that the reward-punishment use harms the 
internal motivation while it generally increases motivation. It can be said that it shows parallelism with related researches.

Marshall (2005) stated that the results of reward and punishment use cannot go beyond short-term solutions. Additionally, he stated that the practices based on extrinsic motivation and so on are obstacles for students to gain their own responsibilities.

According to the views in the literature, the rewards and punishments over-used (more than needed) or misused are to prevent the students from providing internal control. These views can explain the findings reached in this study such as "The behavior provided by reward-punishment use has not a permanent impact on a student." and "The reward-punishment use causes the need for continuous approval.".

Wadsworth (2015) stated that in the cases which a child harms someone else, giving immediately a punishment to the child who harms is the most appropriate feedback to be given. In addition to this, Goleman (2016) stated that self-control is a more permanent structure having more sound bases as cognition, emotion and body, rather than a stop being at that moment. In this study, the finding that participant teachers discovered "The appropriate punishment contributes to selfcontrol in a case like hurting someone" parallels the researches in the literature.

\section{Consequently,}

Participant teachers are to use the reward-punishment according to the criteria they consider appropriate for the purpose of course success, for the purpose of providing the active participation in the lesson and for the purpose of providing the students obtaining more desired behavior.

While teachers use the reward and punishment, they are to confront different problems such as difficulty in following the practices, not being understood the expectations clearly, experiencing inconsistencies, becoming the purpose of the reward, reinforcing the undesired behaviors unwittingly (jealousy, impertinence, etc.), being needed the continuous feedback because of addicting to reward, etc.. According to the teachers, values that are expressed as the permanence of the desired behavior such as being sensitive to the environment, honesty, not wasting, being respectful are not generally gained by the reward-punishment use; rather it can be gained by "setting a good example, using different teaching method-techniques or through concrete experiences". According to the participant teachers, controlled rewards and the use of some punishments are to increase the motivation of the student but this situation is not permanent. In the cases which it is permanent, it is to cause the formation of some undesired values which is realized afterwards. Getting a punishment and not being able to receive a reward successively in the environment given reward affects motivation negatively. According to the participants, if the factors that affect motivation continue for a long time, students can develop positive or negative attitude towards learning. For this reason, reward punishment practices are to require to be applied in a careful, controlled and planned manner. According to the majority of the participant teachers, misusage and the long-term 
reward punishment use even if being correct gives serious damages to more the level of self-control of students when assessed holistically.

It is thought that reinforcement has a great impact on the learning life. However, reward-punishment practices which are not for an individual or individuals, which are based on the same expectation from the whole class lead to unforeseen difficulties when evaluated with the dimensions of the students who receive rewards in the classroom, who do not receive rewards and are punished. In fact, it is seen that the situation which is thought to be appropriate could create unexpected results afterwards. Although it is seen that reward punishment practices provide solutions in the short term, they can cause permanent damages in terms of the affective domain in the long term. For these and other reasons, reward-punishment practice is a subject which should be thought by taking into consideration different dimensions such as a person and people who will be applied, content, expectation criterion and the results that may occur. Meanwhile, this subject should not be thought in a general way, contrarily, it should be thought in a more planned way and in detail. In addition to this, it can be said that the use of different methods and techniques which are considered to be more permanent instead of reward-punishment practices can offer a solution in the longer term.

\section{Recommendation}

- Teachers stated that they had noticed some aspects of their own reward-punishment practices during a qualitative interview. It will be useful for the teachers to carry out different studies they will find the details of their own practices by themselves. In addition to the seminars which the teachers attended as a listener in the training organized during the academic year, etc., it may be useful to include such different studies.

- The thing which the teachers think that they do and the thing they do may not be always the same (Aydin, 2015). In this framework, micro teaching studies can be useful for teachers.

- Teachers can ask for their students to keep a diary that they take short notes on each day (The thing that makes me the happiest in the class today .............. If .............. [happened] today, I would be happier). The effect and change of reward or punishment use on students can be observed through these diaries and compared them with their notes.

- It is seen that the studies investigating the rewardpunishment process and their results are generally the studies that the reward-punishment practices used by others are researched by the secondary people. A study that will be done as "Action Research" on this subject can make a significant contribution to the literature.

- Qualitative research can be carried out to help in-depth understanding towards just one dimension of the reward/punishment about which reward will cause which effect.

- $\quad$ Research can be done about increasing the use of different methods and techniques, and about factors that oblige teachers to use reward and punishment. 
Keywords: Reward punishment practices, affective domain, desired behavior, reinforcement

\section{GíRís}

Öğrencilerin ders başarılarının artırılması, öğrencilere istendik davranışların kazandırılması, sınıf içi düzen ve disiplin sağlanmasına dair, öğretmenlerin sınıflarında en çok başvurdukları yöntemlerden birisi ödül ceza uygulamalarıdır.

Ödül kavramı pekiştirme kavramı ile aynı anlamda kullanılmaktadır. İstenen davranışın ortaya çıkma olasılığının artması için her türlü uyarıcı verilme sürecine pekiştirme denir. Pekiştirme olumlu ve olumsuz pekiştirme şeklinde olabilir. $\mathrm{Bu}$, hoşa gidecek her türlü uyarıcının ortama verilmesi şeklinde yapılıyorsa olumlu pekiştirme, rahatsız eden herhangi bir unsurun ortamdan kaldırılmasıyla yapılıyorsa olumsuz pekiştirmedir. Ceza kavramının ise pekiştirmenin tam tersi olarak kullanıldığı görülmektedir. Ceza; istenmeyen davranışın oluşma sıklığının azalması veya sonlanması için verilir. Ortama hoşa gitmeyecek bir uyarıcının verilmesi 1. Tip ceza, hoşa giden bir uyarıcının ortamdan çekilmesi 2. Tip ceza olarak ifade edilir. Pekiştirme, istenilen davranışın ortaya çıkması veya devam etmesi, ceza ise davranışın azalması veya ortadan kalkması için yapılır (Cüceloğlu, 1990, s. 157; Smith, Hoeksema, Fredrickson ve Loftus, 2015, s. 354). Eğitim alanında düşünüldüğünde, öğrenciye verilen yiyecek, maddi ve sembolik nesneler, övgü, aferin demek, onay vermek, gülümsemek olumlu pekiştirmeye; daha önce verilmiş bir cezayı sonlandırmak, fiziksel anlamda rahatsız eden ses, 1şık, oturma düzeni gibi durumlarda düzenleme yapmak olumsuz pekiştirmeye örnek verilebilir. Fiziksel şiddet, bağırma, sözlü ikazlar, fazladan ödev verme, tahtada bekletme, diğer öğrencilerin yanında rencide etme 1. Tip cezaya; teneffüsten alıkoyma, yapacağı bir etkinlikten mahrum bırakma, öğrenciyi onaylamama, 2. tip cezaya örnek verilebilir.

Pekiştirme, ödül ve ceza kavramları öğrenmenin tarihsel süreci içerisinde ilk olarak öğrenmenin çevre kaynaklı olduğu varsayımına dayanan davranışçılık ekolünde ortaya çıkmıştır. Davranışçı ekolün temsilcilerinden Skinner, laboratuar ortamında fareler ve güvercinler üzerinde yaptı̆̆ 1 deneylerde, farklı şekillerde verilen ödül ve cezaların havyan davranışlarını biçimlendirdiğini gözlemlemiş̧ir. Daha sonra araştırmacılar tarafından, edimsel koşullanma, araçsal şartlandırma olarak bilinen ödül ceza uygulamalarının insanlarda istendik davranışları kazandırma üzerindeki etkisine yönelik çeşitli araştırmalar yapılmış ve bu uygulamalar araştırma bulguları çerçevesinde tartışılmıştır. Ödül ceza, eğitim alanında en çok kullanılan uygulamalardan biridir. Davranışçı yaklaşıma göre hayvanlar üzerinde etkili olan edimsel koşullanmanın (eğitimdeki ödül ceza uygulamalarının) çocuk yetiştirmede de etkili olacağ düşünülmektedir (Cüceloğlu, 2015, s. 154).

Eğitim ile ideal insanı yetiştirme anlayışı "Eğitim Hedeflerini” oluşturmayı gerektirmiştir. Eğitimciler, "hedef" olarak belirtilen insan niteliklerinin belli ölçütlere göre sinıflanabileceğini belirtmişlerdir. 1950'li yıllarda "Öğretim sonunda öğrencide ne tür değişiklikler olacaktır” sorusuna, Bloom ve arkadaşları tarafından, cevaba yardımcı olacak nitelikte bir amaç sınıflaması yapılmıştır. $\mathrm{Bu}$ sınıflama; bilişsel, duyuşsal ve psiko-motor alan olmak üzere üç temel alandır (Çelik, 2006).

Bloom (1956) Eğitim Amaçlarının Taksonomisi adlı kitabında, duyuşsal alanı; ilgi, tutumlar, değerler ve takdirlerin gelişimi olarak belirtmiştir. Başlangıçta ilgi, tutumlar ve değerler olarak ifade edilen duyuşsal alan yapısına, üzerinde çalışılarak ve kavramların tanımlarından yola çıkılarak bu yapıyı ifade eden yeni terimler eklenmiştir. İlk başta tanımlanan duyuşsal alan yapısını referans alarak tanımlar oluşturulmuştur (Darling, 1965). Bu alan, insan davranışlarını şekillendiren tutum, inanç, değer ve öğrenecekleri ile ilgili dikkat, algı, davranış ve merak düzeyleri vb. unsurları kapsamaktadır (Duman ve Yakar, 2017). Duyuşsal alan; tutumlar, değerler, öz denetim, ilgi, merak, motivasyon, öz yeterlilik olarak belirtilebilir (Gable ve Wolf, 1993, s. 2). 
Duyuşsal alan iki ana kısımdan oluşur. İlk kısım, duyuşsal alanın doğasını açıklayan taksonomi öğeleridir: ilgi, tutum, değerler, yargılar. İkinci kısım ise duyuşsal hedeflerin kazanım aşamalarını açılayan, hiyerarşik olarak düzenlenmiş 5 kategoriden oluşmaktadır. Bu hiyerarşi 1 . Alma, 2. Tepkide Bulunma, 3. Değer Verme, 4. Örgütleme, 5. Kişilik Haline Getirme (yani içselleştirme) şeklindedir (Krathwohl, Bloom ve Masia, 1964, s. 35). Duyuşsal alan özelliklerinde ilerledikçe "alma, farkında olma" ile başlayan süreç gittikçe kalıcılaşır ve içselleşme oluşur. Yani birey bir durum veya bir değeri, başka bir durum veya değere tercih etmeyi sağlayan içsel iradeyi gösterir (Wadsworth, 2015, s. ).

Davranışçı yaklaşıma göre, Skinner' in laboratuar araştırmaları sonucunda ödül ve cezanın davranış üzerindeki ulaştığı etki, insanlar için de istendik davranış oluşturmada aynı etkiyi yapar. İçsel veya dışsal pekiştireçler ve cezalar vererek insanların bir davranışı yapmaya karşı merakını uyandırabilir, motivasyonu sağlanabilir (Smith ve diğerleri, 2015, s.234-250). Bilişsel yaklaşıma göre pekiştireçlerin insan motivasyonuna etkisi içsel ve dışsal boyutta farklı değerlendirilir. İkincil yani öğrenilmiş güdülerle ilgili pekiştireçler (para, yıldız verme gibi temsili ödüller) dışsal motivasyonu artırırken içsel motivasyonu azaltır. Fakat birincil döngüyle ilgili olan ve bazı sosyal pekiçtireçler (çikolata, yiyecek, gülümseme gibi sosyal ödüller) içsel motivasyonu artırır. Bununla birlikte bazı pekiştireçlerin içsel motivasyonu artırdığı ifade edilse de, bu durum beklentinin karşılanmasına göre farklılık gösterebilir (Reeve, 2014). Çoğu öğrenme kuramına göre öğrenmede pekiştirmenin gerekli olduğu kuşkusuzdur. Ancak, aynı pekiştireç her öğrencide aynı etkiyi oluşturmayabilir, hatta istenenin tam tersi etki yapabilir. Pekiştirme seçeneklerinin çeşit ve miktar yönüyle sınırlı sayıda olması bazı öğrencilerin doğru pekiştirelememesi anlamına gelmektedir. Ayrıca bir öğretmenin tüm sınıftan aynı pekiştirme ile motive olmasını beklemesi çok doğru olmayacaktır (Bloom, 2016). Temelleri farklı varsayımlara dayansa da, gerek davranışçı yaklaşım (Smith ve arkadaşları, 2015) gerekse diğer yaklaşımlar (Wadsworth, 2015; Bloom, 2016), ödülün ve cezanın istenen sonucu vermesi için doğru kullanımına vurgu yapmışlardır. Ödül ve cezanın verilme şekli, verilme sıklığı ve miktarı, verilme süresi, verilme zamanı, verilen kişi ya da kişilerin uygunluk durumu, dengeli kullanım gibi vb. faktörlerin "doğru kullanım" ifadesi içinde yer aldığı söylenebilir.

Gündoğdu (2007) yaptığı araştırma sonucunda sınıf disiplini sağlamada en çok psikolojik ve sosyal ödüllerin ve cezaların etki ettiği bulgusuna ulaşırken, bu etkinin duyuşsal alan açısından aynı oranda olumsuz etkisinin olabileceği ihtimaline dikkat çekmiştir. Yapılan araştırmalarda, uygun olmayan cezaların verilmesi davranış düzeltme amacından uzaklaşmakta ve öğrencilerin duyusal ve davranış gelişimlerini olumsuz yönde etkilemektedir (Aypay, 2017; Naz, Daraz, Hussain ve Khan, 2012). Yine sınıf içinde verilen cezalar, ceza alan öğrencilerle olan iletişime ve sınıf atmosferine zarar vermektedir (Şahin ve Arslan, 2014). Diğer yandan doğru kullanım dâhilinde ödülün mesajı "yaptığını yapmaya devam et" iken cezanın mesajı "bunu yapma" şeklindedir, ancak ceza, yapılacak olanın ne olduğunu da göstermez. Aynı zamanda ceza, kurum, kişi ya da ortamdan hoşnutsuzluk ve korkunun oluşmasına sebep olur (Smith ve diğerleri, 2015, s. 248).

Aypay (2018), gereksiz miktarda ve gereksiz sıklıkta ödül kullanımının ödül bağımlılığına yol açtığını, ödülün sürekli kullanımının çocuklarda ceza almaya (ödül alamama durumu da olabilir) karşı daha hassaslaşmaya yol açtığını, kaygı oluşturduğunu bulgulamıştır., istenen ödüle ulaşma veya cezadan kaçınma kaygısıyla öğrencilerde yalan söyleme, kopya çekme gibi istenmeyen değer ve davranışların oluşabileceğini belirtmişlerdir. Reeve (2014)'e göre ödüllendirme davranışının, farkedilmesi zor olan üç maliyeti vardır. Bunlar; hedef davranış veya aktiviteye yönelik içsel motivasyonun azalması, öğrenme kalitesininin düşmesi ve öğrencinin kendini düzenleme (öz denetim) yeteneğinin zayıflamasıdır.

Kaufman ve O'Leary (1972) öğrenciler üzerinde istendik davranış kazandırmaya yönelik bir araştırmada, öğretmen tarafından ödüllendirme veya mahrum bırakma yerine, öğrencilerin kendi davranışlarını düşünüp kendilerini ödüllendirmesinin daha kalıcı değişikliği sağladığı sonucuna 
ulaşılmıştır. Yavuzer (2015) ve Gordon (2015), şekil ve miktarı uygun olsa da; ödül ve cezanın uzun süre kullanımının, öğrencinin öz denetimine zarar vereceğini belirtmiştir. Bu ve benzeri uygulamaların dışsal kontrollere olan ihtiyacı devam ettirerek, bireyin öz denetim eksikliğini daha da artıracağını ifade etmiştir.

Derslerde veya okullardaki genel olarak oluşan olumlu ve olumsuz yaşantılar, öğrenmeye ve istenilen durumu yapmaya karşı motivasyonunun şekillenmesini sağlar. Bu yaşantıların sürekliliği halinde olumlu ve olumsuz tutum gerçekleşir. Öğrencide oluşan tutumun nasıl olduğu tüm öğrenme yaşantısı boyunca onun kendini algılamasına eşlik eder. Okul yaşamında kendine dönük algısını, okul yaşamı tecrübeleri aracılığı ile gerçek hayattaki benlik algısına doğru aktarır (Bloom, 2016, s.155160). İnsanlar istesin veya istemesin duygularını ve tutumlarını her nerede olursa olsun yanında taşır. Akademik dersler ve bilişsel yapıların hatırlanması bakımından duyguların önemli bir yeri vardır. Çünkü bireyler hissederek yaptıklarını, içselleştirerek öğrenirler (Arnstine, 1965). Öğrencilerin kendilerini daha rahat hissettiği ortamlarda, duyuşsal yönden zenginleştirilmiş eğitim, öğrenmeye karş1 olumlu tutum gibi duyuşsal unsurlar öğrenmeye olumlu etki oluşturmaktadır (Gömleksiz ve Kan, 2012).

Duyuşsal alan özelliklerinin kazanımı, farkında olma ile başlayıp giderek daha kalıcı hale gelmesi istenen, uzun vadeli ve uzun çaba gerektiren bir süreçtir. Bu süreçte, öğrenciyle birebir iletişimde bulunan kimse olması yönüyle öğretmenler önemli rol almaktadırlar (Gable, 1986; Gömleksiz ve Kan, 2012). Bu sebeple öğretmenlerin uygun gördükleri ölçütlere göre kullandıkları ödül ceza uygulamalarının, öğrencilerin duyuşsal alan özelliklerini nasıl ve ne yönde etkilediğini anlamaya ihtiyaç vardır. Bu araştırmada ele alınan eğitimde kullanılan Ödül-Ceza Uygulamalarının; ders ve okula karşı olumlu tutum oluşturma, ilgi duyma, öğrenmeye karşı motivasyon, hayat boyunca gerek duyulacak öz denetim, ve istendik değer oluşturma boyutları açısından değerlendirilmesinin, literatüre önemli katk1 sağlayacağı düşünülmektedir.

$\mathrm{Bu}$ araştırmanın problem durumu, eğitimde kullanılan ödül ceza uygulamalarının, öğrencilerin duyuşsal alanları açısından değerlendirilmesinine yönelik öğretmen görüşleri nelerdir? Olarak belirlenmiştir.

\section{Araştırmanın Amacı ve Önemi}

$\mathrm{Bu}$ araştırmanın amacı, sınıfta kullanılan ödül ve ceza uygulamalarının öğrencilerin duyuşsal alanları açısından, öğretmen görüşlerine göre değerlendirilmesidir.

$\mathrm{Bu}$ amaç doğrultusunda şu sorulara yanıt aranmıştır:

1. Sınıf yaşamında ödül ceza uygulamaları nasıl, hangi şekilde yer bulmaktadır?

2. Öğretmenlerin ödül ceza uygulamalarının zorluklarına yönelik görüşleri nelerdir ve nasıldır?

3) Öğretmenlerin duyuşsal alana ve ödül ceza uygulamalarına yönelik algıları nelerdir ve nasıldır?

4) Öğretmen görüşlerine göre, ödül- ceza uygulamalarının duyuşsal alan açısından istendik ve beklenmedik (istenmeyen) sonuçları nelerdir ve nasıldır?

Yapılan araştırmalarda, ödül ceza uygulamalarını daha çok istendik ve istenmeyen davranışlar, sınıf disiplini ve genel olarak sınıf yönetimi tartışmaları çerçevesinde ele aldıkları görülmüştür. Araştırmalarda, en çok veya en sık kullanılan ödül ceza yöntemleri gibi daha çok nicel olan çalışmalara rastlanmıştır (Çolak, 2005; Gündoğdu, 2007; Sadık, 2008; Yılmaz, 2011; Yılmaz ve Babaoğlan, 2013).

Ödül ceza uygulamaları sınıflarda akademik başarı ve istendik davranış kazandırma amacıyla kullanılırken; öğrencilerin motivasyon (merak-ilgi), tutum, öz denetim ve değer kazanımı boyutlarının bu uygulamalardan nasıl etkilendiğinin anlaşılmasına ihtiyaç vardır. $\mathrm{Bu}$ araştırma, ödül ceza 
uygulamalarının duyuşsal alanın belirtilen unsurları açısından, nasıl bir rolü olduğunu derinlemesine anlamaya yönelik olması yönüyle önem arz etmektedir. Araştırma sonucunda elde edilen bulguların, öğretmenlere duyuşsal alan ve ödül- ceza uygulamaları hakkında farkındalık sağlayacağı düşünülmektedir. Bununla birlikte ödül ceza uygulamalarının olumlu ve olumsuz sonuçlarına dair bulguların, sınıf içi uygulamaların yeniden değerlendirilmesine, farklı uygulamalara dikkat çekilmesine katkı sağlayacağı düşünülmektedir. Konunun benzer çalışmalar hususunda araştırmacılara fikir vermesi de beklenmektedir.

\section{Yöntem}

\section{Araştırmanın Modeli ve Deseni}

$\mathrm{Bu}$ araştırma bir nitel araştırma yöntemi ile yapılmış olup, durum çalışması deseni kullanılmıştır. Durum çalışması: Bir ya da birkaç durumun derinliğine araştırılmasıdır. Amaç belirli durumlara ilişkin sonuçlar ortaya koymaktır. Durum çalışması "nasıl, niçin ve ne" sorularını temele alan, araştırmanın bir olgu ya da durumu derinlemesine incelemesine imkân veren araştırma yöntemidir (Patton, 2016). Bu araştırmada durum çalışması, eğitimde kullanılan ödül ceza uygulamalarının öğrencilerin duyuşsal alanları açısından nasıl olduğunun, öğretmenlerin deneyimlerine göre derinlemesine anlamaya yöneliktir.

\section{Çalışma Grubu}

Araştırmanın çalışma grubunu, İstanbul İl Milli Eğitim Müdürlüğü' ne bağlı çalışan, 4 okul öncesi öğretmeni, 4 (ilkokul) sınıf öğretmeni ve 3 PDR uzmanı olmak üzere, 11 öğretmen oluşturmaktadır. Hizmet süreleri 2 ile 20 yıl arasında değişen çalışma grubunda 5 erkek 6 kadın öğretmen bulunmaktadır. Çalışma grubu amaçlı örnekleme tekniklerinden biri olan ölçüt örnekleme yoluyla seçilmiştir.

Amaçlı örnekleme tekniği olan ölçüt örnekleme; önceden belirlenmiş ölçütleri karşılayan durumların çalışıldığı örneklemedir (Yıldırım ve Şimşek, 2011). Bu çalışmada, öğretmenlerin ödül ve ceza uygulamalarını sınıflarında deneyimlemiş olmaları ölçütü aranmıştır. PDR uzmanları için okullarında ödül ve ceza uygulayan öğretmenlerin süreçleri hakkında bilgi ve paylaşım sahibi olmaları ölçütü aranmıştır.

Tablo 1: Çalışma grubu

\begin{tabular}{llll}
\hline Kat1lımc1lar & Cinsiyet & Eğitim düzeyi & Kidem Y1l1 \\
\hline Kat1lımc1 OÖ1 & Kadın & Y.Lisans & 7 \\
\hline Kat1lımc1 OÖ2 & Kadın & Lisans & 8 \\
\hline Kat1lımc1 OÖ3 & Kadın & Lisans & 20 \\
\hline Kat1lımc1 OÖ4 & Kadın & Lisans & 13 \\
\hline Kat1lımc1 SÖ1 & Erkek & Y.Lisans & 14 \\
\hline Kat1lımc1 SÖ2 & Erkek & Y.Lisans & 12 \\
\hline Kat1lımc1 SÖ3 & Kadın & Lisans & 9 \\
\hline Kat1lımc1 SÖ4 & Erkek & Lisans & 19 \\
\hline Kat1lımc1 PDR1 & Erkek & Y. Lisans & 2 \\
\hline Kat1lımc1 PDR2 & Kadın & Lisans & 5 \\
\hline Kat1lımc1 PDR3 & Erkek & Y. Lisans & 13 \\
\hline
\end{tabular}

\section{Veri Toplama Süreci}

Araştırmada veriler, yarı yapılandırılmış görüşme tekniği kullanılarak, yarı yapılandırılmış görüşme formu aracıllı̆ıyla elde edilmiştir. Yarı yapılandırılmış görüşmede, araştırmacı önceden sormayı planladığı soruları içeren görüşme formunu hazırlar, bununla birlikte görüşmenin akışına bağlı olarak farklı ya da alt sorular sorarak görüşmeye devam edebilir (Karasar, 2008). Bu teknik 
duruma göre daha ayrıntılı bilgi alma, duruma göre bazı soruların birlikte sorulması veya yer değiştirmesi gibi hususlarda araştırmacıya esneklik tanıyan bir yaklaşımdır (Yıldırım ve Şimşek, 2011).

Araştırmanın nitel verilerinin toplanması için araştırmacılar tarafından geliştirilen yarı yapılandırılmış görüşme formunun hazırlanmasında 2 alan uzmanından görüş alınmış ve temel sorularla birlikte sonda sorular oluşturulmuştur. Görüşmelere başlamadan önce 3 öğretmen ile ön görüşme yapılmış; ardından görüşme formuna son hali verilmiştir. Yarı yapılandırılmış formda yer alan bu soruların yanı sıra, görüşmeler sırasında gerekli görüldükçe ek sorular da yöneltilmiştir. Öncesinde öğretmenlerden randevu alınarak yapılan görüşmeler, okulda boş bulunan sinıflarda yüzyüze gerçekleştirilmiştir. Yaklaşık 30 - 40 dakika süren öğretmen görüşmeleri ses kayıt cihazıyla kaydedilmiştir.

\section{Verilerin Analizi}

Yapılan görüşmelerden elde edilen veriler, nitel veri analiz yöntemlerinden biri olan betimsel analiz tekniği kullanılarak analiz edilmiştir. Alt amaçlar kapsamında sorulan araştırma soruları esas alınarak elde edilen betimlemeler, kodlanarak kategoriler belirlenmiştir. Elde edilen veriler ilgili alt amaç dahilinde, belirlenmiş kategorilere göre sunulmuştur. Daha sonra bu kategoriler ve betimlemeler yorumlanarak araştırmanın sonuçlarına ulaşılmıştır. Araştırmada bireylerin görüşlerini yansıtmak amacıyla doğrudan alıntılara da yer verilmiştir. Benzer şekillerde olan betimlemelere, bulgularda temsili olalarak yer verilmiş ancak; yorum, sonuç ve tartışma kısmı tüm cevaplar göz önünde bulundurularak yapılmıştır.

\section{Bulgular ve Yorumlar}

Bu bölümde yarı yapılandırılmış görüşmelerden elde edilen ve 4 alt amaç kapsamında yer alan araştırma sorularının cevaplarına yer verilmiştir. Öğretmenlerin cevapları verirken soruları, ödül alan, ödül alamayan ve ceza alan öğrenciler boyutu ile cevaplaması istenmiştir.

Alt Amaç 1: Sınıf yaşamında ödül- ceza uygulamaları nasıl, hangi şekilde yer bulmaktadır?

1. Soru: Sinıfta ödül ve cezayı ne şekilde veriyorsunuz?

2. Soru: Hangi durumlara ödül veya ceza verirsiniz?

3.Soru: Ödül veya cezayı verirken, daha çok hangi ölçütleri sağlamasına dikkat edersiniz?

Alt Amaç 2: Öğretmenlerin ödül ceza uygulamalarına yönelik görüşleri nelerdir ve nasıldır?

4. Soru: Ödül ve cezayı uygularken sorunlar yaşanıyor mu, ne gibi sorunlar yaşanıyor açıklar misiniz?

Alt Amaç 3: Öğretmenlerin duyuşsal alana ve ödül ceza uygulamalarına yönelik algıları nelerdir ve nasildır?

7. Soru: Sizce ödül ve ceza kullanımı ile çevreye duyarlılık, dürüstlük, saygılı olma, vb. gibi istendik davranış olarak ifade edilen- değerleri kazandırabilir miyiz? Ödül ceza kullanmadan nasıl kazandırabiliriz? Açıklar mısınız?

Alt Amaç 4: Öğretmen görüşlerine göre, ödül- ceza uygulamalarının duyuşsal alan açısından istendik ve beklenmedik (istenmeyen) sonuçları nelerdir ve nasıldır?

5. Soru: Ödül ceza uygulamalarının, öğrencilerin duyuşsal alanları açısından olumlu etkilerini nasıl değerlendirirsiniz?

6. Soru: Ödül ceza uygulamalarının, öğrencilerin duyuşsal alanları açısından olumsuz etkileri neler olabilir, nasil değerlendirirsiniz? 


\section{Sınıf Yaşamında Ödül- Ceza Uygulamalarının Nasıl, Hangi Şekilde Yer Bulmakta Olduğuna Yönelik Bulgular}

Tablo 2. Sınıfta ödül ve cezayı nasıl veriyorsunuz? Sorusuna Verilen Cevaplar

\begin{tabular}{|c|c|}
\hline Kategoriler & Betimlemeler \\
\hline Maddi ödüller & $\begin{array}{l}\text { Somut ödüller, kumbara, kitap, çikolata, dondurma gibi küçük hediyeler (SÖ1, SÖ2, } \\
\text { SÖ3, OÖ4). } \\
\text { Öğrenciye sorarak beğendiği bir hediye almak (SÖ4). }\end{array}$ \\
\hline Sembolik ödüller & $\begin{array}{l}\text { Yıldız, yaka kart1, gülenyüz verme, eline resim çizme (OÖ3, OÖ4, OÖ1, SÖ1, SÖ3). } \\
\text { Öğrenciye yönelik başarı belgesi, elma kızartma uygulaması, ağaca resim asma (SÖ1, } \\
\text { SÖ2, SÖ3). }\end{array}$ \\
\hline Sosyal ödüller & $\begin{array}{l}\text { Alkışlatma, aferin, ayın veya haftanın öğrencisinin seçilmesi, sınıf önünde kupa (vb. } \\
\text { hediye) verme gibi sosyal ödüller (OÖ3, SÖ1, SÖ2, SÖ3, SÖ4). } \\
\text { Alkışlatma veya aferin verme (OÖ1). } \\
\text { Örnek gösterme (OÖ4). }\end{array}$ \\
\hline $\begin{array}{l}\text { 1. Tip ceza: } \\
\text { (Öğrenciye istenmeyen } \\
\text { durumun verilmesi) }\end{array}$ & $\begin{array}{l}\text { Sözlü uyarıda bulunma(OÖ1, SÖ1, SÖ2, SÖ3, SÖ4). } \\
\text { Ek ödev veya görev verme (SÖ1, SÖ2, SÖ3). } \\
\text { İdareye yönlendirme (SÖ3). } \\
\text { Kapıda bekletme (SÖ2, SÖ3, SÖ4). }\end{array}$ \\
\hline $\begin{array}{l}\text { 2. Tip ceza: } \\
\text { (Öğrencinin istediği } \\
\text { bir durumdan mahrum } \\
\text { birakılmasi) }\end{array}$ & $\begin{array}{l}\text { Birbirine zarar verme ve kötü söz söyleme gibi durumlarda; etkinlikten, ortamdan, } \\
\text { teneffüsten mahrum bırakma (OÖ1, OÖ3, OÖ4, SÖ1, SÖ2, SÖ3). }\end{array}$ \\
\hline $\begin{array}{l}\text { Kullanmayı Tercih } \\
\text { Etmiyorum }\end{array}$ & $\begin{array}{l}\text { Daha önceki dönemlerde kullanıyordum, artık ödül ve ceza adı altında kullanmaktan } \\
\text { kaçınmaya çalışıyorum. }\end{array}$ \\
\hline
\end{tabular}

Tablo 2 incelendiğinde, katılımc1 öğretmenlerin ödülü; maddi, sembolik ve sosyal ödüller şeklinde kullandığı görülmektedir. Yine katılımcı öğretmenlerin cezayı, mahrum bırakma seklinde 2. Tip ceza olarak ve ek görev verme, sözlü uyarıda bulunma şeklinde 1. Tip ceza olarak kullandıkları görülmektedir. Bir öğretmenin ise ödül ve ceza kullanımını tercih etmediği görülmektedir.

Tablo 3.Hangi durumlara ödül veya ceza verirsiniz? Sorusuna Verilen Cevaplar

\begin{tabular}{|c|c|}
\hline Kategoriler & Betimlemeler \\
\hline \multirow{3}{*}{ Ders Katılım Durumu } & $\begin{array}{l}\text { Derste parmak kaldırma, dikkatli dinleme, ödev ve etkinlikleri yapma durumları } \\
\text { (SÖ1, SÖ2, SÖ3, SÖ4). }\end{array}$ \\
\hline & Verilen çalışmayı doğru ve güzel yapma durumları (OÖ1, OÖ3). \\
\hline & $\begin{array}{l}\text { Dersin sorumluluklarını yerine getirme durumları (OÖ1, OÖ3, OÖ4, SÖ1, SÖ2, } \\
\text { SÖ3, SÖ4). }\end{array}$ \\
\hline \multirow{3}{*}{ Başarı Durumu } & Test, sınav başarı durumları (SÖ1, SÖ2, SÖ3, SÖ4). \\
\hline & $\begin{array}{l}\text { Kitap okumaya yönelik başarı durumları (Hızlı okuma, çok okuma) (SÖ1, SÖ2, } \\
\text { SÖ3). }\end{array}$ \\
\hline & Yarışma ve etkinliklerdeki başarı durumları (OÖ1, OÖ3, SÖ1, SÖ2, SÖ3, SÖ4). \\
\hline \multirow{2}{*}{$\begin{array}{l}\text { Davranış Durumları } \\
\text { ve Kurallara Uyma }\end{array}$} & Arkadaşlarıyla iyi geçinme (OÖ1,OÖ3, OÖ4, SÖ1, SÖ2, SÖ3, SÖ4). \\
\hline & $\begin{array}{l}\text { Başkalarına zarar verme durumu ve söylemler (OÖ1, OÖ3, OÖ4, SÖ1, SÖ2, SÖ3, } \\
\text { SÖ4). }\end{array}$ \\
\hline
\end{tabular}

Turkish Studies - Educational Sciences

Volume 14 Issue 3, 2019 
Temizlik, düzen (OÖ3, SÖ3).

Derste sessiz durma (OÖ1, SÖ3).

Sınıf kurallarına uyma (OÖ1, OÖ3, OÖ4, SÖ3).

Tablo 3 incelendiğinde, katılımcı öğretmenlerin, ödülü ve ceza kullanımlarını 3 durum kapsamında belirttikleri görülmüştür. Öğretmenler ödül ve cezayı, ögrencilerin derslere katıllm durumlarına, başarı gösterme durumlarına ve en çok davranış durumlarına göre kullanmaktadırlar.

Tablo 4. Ödül veya cezayı verirken, daha hangi ölçütleri sağlamasına dikkat edersiniz? (Neye göre ödül veya ceza verirsiniz?) Sorusuna Verilen Cevaplar

\begin{tabular}{|c|c|}
\hline Kategoriler & Betimlemeler \\
\hline \multirow{5}{*}{$\begin{array}{l}\text { Siralamada } \\
\text { Önde Olma } \\
\text { Durumu }\end{array}$} & $\begin{array}{l}\text { Bir soruyu ilk önce yapan üç kişiye yıldız, haftalık kitap okuma sayısında 1. olana belge, } \\
\text { dönem içinde dersi dinleme de verdiğim gülen yüzlerde ilk on ögrenciye ödül verme gibi } \\
\text { diyebilirim (SÖ3). }\end{array}$ \\
\hline & $\begin{array}{l}\text { Duruma göre en iyi yapanı, en başarılı olanı alkışlatma, ilk üç kişiye aferin verme, ayın } \\
\text { öğrencisi seçme şeklinde ödüllendiriyorum (SÖ1). }\end{array}$ \\
\hline & Ders içi veya ders dıșı gönüllü katıldıkları etkinlilerde dereceye giren öğrencilere farklı \\
\hline & $\begin{array}{l}\text { ödüller veririm, ama herkesin katıldığı çalışmalarda sıralamaya bakmam, hepsine veririm } \\
\text { (SÖ2). }\end{array}$ \\
\hline & $\begin{array}{l}\text { Yemeğini en güzel yemek, masasını en temiz tutmak, en çabuk toparlanmak gibi konularda ilk } \\
\text { yapanlara yıldız, alkışlatma veya aferin gibi ödüller veriyorum (OÖ3). }\end{array}$ \\
\hline \multirow{6}{*}{$\begin{array}{l}\text { Kriteri } \\
\text { Sağlama } \\
\text { Durumu }\end{array}$} & $\begin{array}{l}\text { Mesela etkinliği tamamlayan herkesin eline resim çizeceğim diyorum, tamamlayan herkese } \\
\text { çiziyorum (OÖ3). }\end{array}$ \\
\hline & $\begin{array}{l}\text { Saygılı olma, sınav başarısını artırma gibi kriterleri sağlayan her öğrenciye onun seveceği bir } \\
\text { hediye alırım, ödül alması için o davranıș1 göstermiş olması lazım (SÖ4). }\end{array}$ \\
\hline & Örnek bir davranış ya da başarı göstermişse onlara veriyorum, ama sayısını fazla tutmaya \\
\hline & çalışırım, mesela 20 kişide 8 - 10 kişi gibi. Hani 1 . olmuş, 2. olmuş veya ilk üçte gelmiş gibi... \\
\hline & Bunlardan özellikle kaçınırım (OÖ4). \\
\hline & $\begin{array}{l}\text { Yanlış davranış, ders düzenini fazlasıyla bozma, başkalarına zarar verme gibi durumlarda } \\
\text { mecburen bir şeylerden mahrum bırakıyoruz (SÖ3). }\end{array}$ \\
\hline \multirow{2}{*}{$\begin{array}{l}\text { Bireysel } \\
\text { Örneklik } \\
\text { Durumu }\end{array}$} & $\begin{array}{l}\text { Normalde de veririm ama davranışıyla o şeyi çok güzel temsil eder, çok farklı bir şey başarır, } \\
\text { o zaman gerçekten ödüllendirilmelidir ki, bende ödül takdim ederim (SÖ4). }\end{array}$ \\
\hline & $\begin{array}{l}\text { Bazen yaptığı davranış kötü bir örnekse, mecburen tahtada ya da kapıda bekleme cezası } \\
\text { veriyorum (SÖ3). }\end{array}$ \\
\hline \multirow{2}{*}{$\begin{array}{l}\text { Katılim } \\
\text { Durumu }\end{array}$} & $\begin{array}{l}\text { Örneğin sınıf kitap okudu } 3 \text { veya } 5 \text { hepsine başarı belgesi hazırlarım. Haftanın öğrencisini } \\
\text { seçiyorsam da hepsinin almasını sağlayacak şekilde onu ben ayarlarım, herkes mutlaka bir } \\
\text { ödül alır yani (SÖ2). Ama dereceye girer, ona da katılım belgesinin yanında daha özel bir } \\
\text { hediye daha veririm. }\end{array}$ \\
\hline & $\begin{array}{l}\text { Bir yarışma veya etkinliğe katılan herkese teşekkür ederim 1., 2. , kazanan - kaybeden } \\
\text { demem, çok güzel yarışan A takımı ve çok güzel yarışan B takımı derim, herkes kendini } \\
\text { alkışlasın derim. Verdiğimde hepsine hediye şeklinde veriyorum genelde (OÖ2). }\end{array}$ \\
\hline
\end{tabular}

Tablo 4 incelendiğinde, katılımcı öğretmenlerin, ödül ve ceza kullanımlarını 4 ölçüt kapsamında belirttikleri görülmüştür. Tabloya göre öğretmenler ödülü, belirledikleri kriterlerin sağlanmasına göre, öğrencilerin bir konuda örnek teşkil etmesi durumuna göre, yapılan çalışmaya katılım durumuna göre ve bir seyi ilk yapan, en çok yapan veya dereceye giren öğrenciye verme gibi sıralamada önde olma durumuna göre kullanmaktadırlar. Tabloya göre bazı öğretmenlerin, siralama durumu ölçütünü kullanmaktan özellikle kaçındıkları görülmektedir. 
Tablo 5. Ödül ve cezayı uygularken sorunlar yaşanıyor mu, ne gibi sorunlar yaşanıyor açıklar mısınız?

Sorusuna Verilen Cevaplar (Bütün öğretmenler yaşanıyor cevabı vermiştir)

\begin{tabular}{|c|c|}
\hline Kategoriler & Betimlemeler \\
\hline $\begin{array}{l}\text { Ödül, Ceza } \\
\text { Algisindaki } \\
\text { Farkl111klar }\end{array}$ & $\begin{array}{l}\text { Düşünme sandalyesinde bekletiyorum örneğin, bekliyor ama düşünmüyor, somut işlem döneminde } \\
\text { ödül de cezada verilirken nedenleri çok iyi anlatılmalı yoksa anlamı kalmaz, anlamaz ki çocuk } \\
\text { (OÖ1). } \\
\text { Vaat ettiğiniz ödül her öğrencide aynı motivasyonu sağlamıyor, onu ödül olarak görmeyebiliyor, } \\
\text { aynısı cezada da olur (OÖ3). } \\
\text { Diyelim deste gürültü yaptı, kapıda bekleme cezası alsın, ama ona ödül gibi gelir (OÖ2). }\end{array}$ \\
\hline $\begin{array}{l}\text { Takip Zorluğu- } \\
\text { Tutarsız Olma }\end{array}$ & $\begin{array}{l}\text { Ödülün takibi zamanla zorlaştığı için tutarlılık azalıyor, anlamı düşüyor, bazen ben bile } \\
\text { unutuyorum, yarıda bırakıyorum, oluyor yani (OÖ1). } \\
\text { Adaleti sağlamak çok zor, ne kadar sağllyorum desek de gözden kaçan oluyor, bizim için } 20 \text { kişi de } \\
\text { bir ama çocuk için büyük tutarsızlık olarak anlaşılabiliyor tabi, ben o yüzden ödüldeki mantığımı } \\
\text { biraz değiştirdim (SÖ2). } \\
\text { Öğretmenler sınıfların kalabalık olmasını ödül ceza kullanımını için zorunlu görüyorlar, başlarda en } \\
\text { çok bu konu üzerinde duruluyor, ama sonra takip noktasında enerji israfını beraber yaşıoruz } \\
\text { (PDR3). } \\
\text { Ödül ve ceza kolay gibi görünen ama hakkını vermesi zor bir yöntem aslında. Bu sınıf } \\
\text { mevcutlarıla kısa vadede günü kurtarmaya yönelik ama kurtarmıor da... (SÖ1). }\end{array}$ \\
\hline $\begin{array}{l}\text { Ödülün } \\
\text { Amaçsallaşması }\end{array}$ & $\begin{array}{l}\text { Ödülün sürekli kullanımı, öğrencide bilgiden çok ödülü merak etmeye dönüşebilir, çocuk ödülü } \\
\text { alıyor niye aldığını hatırlamıyor gibi komik bir durum oluyor tabi bazen (SÖ1). } \\
\text { Birde veli boyutu var, veli ödülün takipçisi... Çocuğun aldığı ödülü sosyal medyada paylaşma, } \\
\text { başka kimlerin aldığını merak etme, hani bir tek bizde mi var herkeste mi? Bazı veliler için çok } \\
\text { önemli (SÖ2). }\end{array}$ \\
\hline $\begin{array}{l}\text { İstenmeyen } \\
\text { Durumu } \\
\text { Pekiştirme }\end{array}$ & $\begin{array}{l}\text { Dikkatten kaçarsa ya da dengeli olmazsa ödül, aslında gizil kazanımlar oluşur. Öğretmen farkına } \\
\text { varmadığı yanlış davranışı pekiştirebilir. Ya da alması gereken bir öğrenci gözden kaçırılabilir, ona } \\
\text { da ceza olmuş olur (PDR2). } \\
\text { Tabi ceza alınca ya da ödülü üst üste alamazsa kaygısı artar, kaygısızlığı da artar aslında... Ama } \\
\text { gerçek hayatta böyle, ödülü hak eden alır ki anlamı olsun, ben demiyorum Gatto diyor ( Bir kitap } \\
\text { yazarını kastediyor) (SÖ4). } \\
\text { Ödül aslında zayıf öğrencilere çözüm amaçlı başlıyor, ama sonrasında başarılı ve başarısız öğrenci } \\
\text { arasındaki farkın açıldığını görüyoruz bazı sınıflarda (PDR3). }\end{array}$ \\
\hline Ödül Bağımlılığı & $\begin{array}{l}\text { Öğretmenler çocukların her ayrıntıyı sormalarından şikayetçi, ama sınıflarda davranışlar genelde } \\
\text { ödüle bağlı, çocukta artık haklı olarak aferin de olsa bir onay bekliyor (PDR2). } \\
\text { Mesela heyecanlı bir şekilde bir fikir söyleyince hocam, ödül ne diye soruyor çoğunluğu (SÖ3). } \\
\text { Özellikle sürekli ödül alan çocuklar için durum normalleşir, yaş da ilerleyince aynı etkiyi sağlamaz, } \\
\text { ödülü değiştirmek ama bırakmamak gerekir bence (SÖ4). }\end{array}$ \\
\hline $\begin{array}{l}\text { Kalıplaşmış } \\
\text { Yargılar }\end{array}$ & $\begin{array}{l}\text { Bizde böyle bir sistemde öğrencilik geçirdik, belki ondan bilmiyorum, kalıcı olmadığını bilsem de, } \\
\text { direk bu yöne yöneliyorum (SÖ1). } \\
\text { Ödül kullanımına nerden başladım hatırlamıyorum... Çok yaygın olduğu için o kadar kalıplaşmış ki } \\
\text { sanki başka yöntem yokmuş gibi olmuş (OÖ1). }\end{array}$ \\
\hline
\end{tabular}

Tablo 5 incelendiğinde, öğretmenlerin ödül ve cezayı kullanırken karşılaştığı sorunları, 7 boyutta ifade ettikleri görülmüştür. Bu boyutlar, aynı uygulamaya yönelik algılarda farklllıklar olması, takibinin zor olması ve tutarsızlıklar yaşanması, ödülün istenen kazanımın ötesine geçip ödülün amaç haline gelmesi, farkında olmadan istenmeyen durumun pekiştirilmesi, ödül bağımlılı̆̆ oluşması yani sürekli dönüt ihtiyacı ve kalıplaşmış yargılar olması şeklindedir. 
Tablo 6. Ödül ceza uygulamalarının, öğrencilerin duyuşsal alanları açısından olumlu etkilerini nasıl değerlendirirsiniz? Sorusuna Verilen Cevaplar

\begin{tabular}{|c|c|}
\hline Kategoriler & Betimlemeler \\
\hline $\begin{array}{l}\text { Motivasyonun } \\
\text { Artış1 } \\
\text { (İlgi) }\end{array}$ & $\begin{array}{l}\text { Ödül alan öğrencinin motivasyonu artar, çok abartı değilse, cezayla da bazı öğrencilerin } \\
\text { daha çok çabaladığını görüyorum ki, olurda bence... Bunu kendimizde de görüyoruz } \\
\text { (SÖ1). } \\
\text { Motivasyon olması için teşvik şart ve sağlar da (SÖ2). } \\
\text { Başarma duygusu desteklendikçe motive oluyor (SÖ3). }\end{array}$ \\
\hline $\begin{array}{l}\text { Olum } \\
\text { Geliş }\end{array}$ & $\begin{array}{l}\text { Motive olan öğrenci derse karşı olumlu tutum geliştirir (SÖ4). } \\
\text { Ödül ve ceza gerçekten dikkatli kullanıldığında, davranışsal boyut oturdukça olumlu } \\
\text { tutum gelişmesini sağlayabilir (PDR3). } \\
\text { Ödüllendirildikçe okulu, öğretmenini sever, öğrenme sevgisi kalıcı olmaya başlar (OÖ3). }\end{array}$ \\
\hline $\begin{array}{l}\text { Kendini Kontrol } \\
\text { (Öz Denetim) }\end{array}$ & $\begin{array}{l}\text { Uygun verilen ceza kendini kontrol açısından katkı sunabilir (SÖ1). } \\
\text { Düşünme köşelerinde bekleme gibi. Adına ceza demeyelim ama bazı uygulamalar } \\
\text { diyelim. Kendini kontrol konusunda faydalı olur bana göre (OÖ3). } \\
\text { Mesele onu anlamasını sağlamak, gerçekten anlayacağ1 şekilde izah edersek, bazen } \\
\text { durdurmak, ara verdirmek, sözlü uyarmak kendisini kontrol etmesini sağlar, en azından } \\
\text { yatıştırır. }\end{array}$ \\
\hline
\end{tabular}

Tablo 6 incelendiğinde, katılımcı öğretmenler dengeli ödül kullanımının, motivasyon ve olumlu tutum geliştirmeye olumlu yönde katk1 sunacağını belirtmişlerdir. Tabloya göre katılımcı öğretmenler uygun şekilde verilen cezanın kendini kontrol boyutuna olumlu yönde katkı sunacağını belirtmişlerdir.

Tablo 7. Ödül ceza uygulamalarının, öğrencilerin duyuşsal alanları açısından olumsuz etkileri neler olabilir, nasıl değerlendirirsiniz? Sorusuna Verilen Cevaplar

\begin{tabular}{|c|c|}
\hline Kategoriler & Betimlemeler \\
\hline $\begin{array}{l}\text { Motivasyonda } \\
\text { Düşme } \\
\text { (İlgi) }\end{array}$ & $\begin{array}{l}\text { Üst üste ödül almazsa tabi üzülür, ilgisini kaybeder, merakını kaybeder, kapılar kapanmaya } \\
\text { doğru gider o zaman. Ödül vermek için firsatlar kollarım o yüzden, ama yine de gayret } \\
\text { etmiyorsa alamayadabilir tabi (SÖ4). } \\
\text { Doğrusu ödülü, örnek olsun, sinıfta başarı farkı azalsın diye kullanıyoruz, yine yapan motive } \\
\text { oluyor, yapamayan daha ilgisizleşiyor bazı zamanlar, fark daha da açılıyor, sanırım bunu } \\
\text { şimdi fark ettim... (SÖ1). } \\
\text { Ceza alan öğgrenci de kaygyya bağlı ilgisizleşir (OÖ2). } \\
\text { Tabi, merak ödüle oluyor çoğunlukla, merak asıll görevini alamayabilir (PDR3). } \\
\text { Motive kaybıyla beraber, duyarsızlaşma olabilir ki bu hoş olmaz (OÖ2). }\end{array}$ \\
\hline $\begin{array}{l}\text { Olumsuz Tutum } \\
\text { Geliştirme }\end{array}$ & $\begin{array}{l}\text { Hiç ödül alamadıysa, küser tabi, üzülür, hatta okuldan nefret eder belki ama aşar, bu her } \\
\text { yerde karşısına çıacak (SÖ4). } \\
\text { Bir iki olumsuz örneğin tutuma genelleneceğini düşünmüyorum ama takip edilmez üst üste } \\
\text { ceza alırsa veya başkaları alırken ödülsüz kalırsa, o zaman tutuma olumsuz yansır, takip } \\
\text { gerek, onu öğretmenin ayarlaması lazım (SÖ2). }\end{array}$ \\
\hline $\begin{array}{l}\text { Öz Denetim } \\
\text { Eksikliği }\end{array}$ & $\begin{array}{l}\text { En sıkıntılı kısmı, kendini kontrol meselesi bence, düşünsenize bu sene öğrettim diyorsunuz } \\
\text { seneye yok, çöpü yine atıor yere örneğin. Kısa vadeli kalıyor, ara verince unutuyor, ailesi } \\
\text { dikkat ediyorsa bu tarz konulara o zaman unutmaz tabi (SÖ3). } \\
\text { Dönüt beklentisinden ve tutarlılık olmadığından olabilir, çocuklarda bir işi başlatma, kendi } \\
\text { kararına göre devam etme ve bitirme konularında zarar verir tabi (PDR2). } \\
\text { Hem duruma göre düşünsün diyoruz, hem tam itaat bekliyoruz, iç kontrolde arada kalıyor } \\
\text { çocuklar (OÖ2). }\end{array}$ \\
\hline $\begin{array}{l}\text { İstenmeyen } \\
\text { Değer Oluşumu }\end{array}$ & $\begin{array}{l}\text { Hepsinde değil tabi ama denge olmazsa çok ödül alan bazı çocuklarda şımarıklık, alay etme, } \\
\text { alamayanlarda kıskançlık oluşuyor (SÖ4). } \\
\text { Onaylanma, övgü düşüncesiyle şikâyet etme, yalan söyleme, gibi davranışlar oluşabiliyor, } \\
\text { cezadan almamak içinde söylenebilir tabi (OÖ2). } \\
\text { Öğretmen hiç kullanmasa da, gözde öğrenci, ya da yaramaz problemli öğrenci gibi etiketler }\end{array}$ \\
\hline
\end{tabular}


bütün olmaya engel oluyor, o yüzden kayıp ve kazançları gruplara yaymaya çalışırım (OÖ4).

Tablo 7 incelendiğinde, katılımc1 öğretmenler (ödül verilen ortamda) üst üste ödül alamama ve ceza almanın motivasyonu olumsuz yönde etkilediğini, ilgi ve merak kaybına yol açtığını belirtmişlerdir. Düşen motivasyona ve ilgiye bağl1, olumsuz tutum geliştirmeye yol açabileceğini belirtmişlerdir. Tabloya göre katılımcı öğretmenlerin, ödül ceza uygulamalarının dengeli kullanılmamasının, öğrencilerin öz denetimlerini kazanmalarına zarar verdiğini ve öğrencilerde istenmeyen değerlerin oluşmasına yol açtığını belirttiği görülmektedir.

Tablo 8. Sizce ödül ve ceza kullanımı ile çevreye duyarlılık, dürüstlük, saygılı olma, vb. gibi -istendik davranış olarak ifade edilen- değerleri kazandırabilir miyiz? Ödül ceza kullanmadan nasıl kazandırabiliriz? Açıklar mısınız?

\begin{tabular}{|c|c|c|}
\hline Kategoriler & & Betimlemeler \\
\hline \multirow{3}{*}{$\begin{array}{l}\text { Ödül Ceza ile } \\
\text { Kazandırılamaz }\end{array}$} & Örnek Olma & $\begin{array}{l}\text { Değer örnek olma ile olur, çocuk sizi görür öğretmenim dürüst } \\
\text { der, temiz der sizi sever öyle kazanır (SÖ4). } \\
\text { Öğretmen değeri taşır, yaşar, değeri hissettirir, ödül daha somut } \\
\text { şeylerde işe yarar değerde çok soyut kalır (SÖ2). } \\
\text { Örnek olur, o senden gördüğünü alır zaten (OÖ4). }\end{array}$ \\
\hline & $\begin{array}{l}\text { Farklı Yöntem } \\
\text { Teknikler Kullanma }\end{array}$ & $\begin{array}{l}\text { Kötü söz söylemenin zararını anlayamıyorlardı bir türlü, pirince } \\
\text { güzel söz söyleme deneyi var hani onu yaptık bir hafta boyunca } \\
\text { mesela, baya azalma gördüm (OÖ1). } \\
\text { Mesela drama yaptırıyorum, zarar verdikleri kişi oluyorlar } \\
\text { bazen, öğretmen oluyorlar bazen o gözle bakıyorlar olaylara } \\
\text { (OÖ4). } \\
\text { Oyun ve farklı etkinlikleri deniyorum. İlk zamanlar en çabuk } \\
\text { kim temizleyecek derdim, şimdi hepsine "temiz avcılar" bilekliği } \\
\text { yaptırdım oyun gibi yapıorlar, zamanla değer haline gelecektir, } \\
\text { bir kişiye değil herkese verilmiş sorumluluk çünkü (OÖ2). }\end{array}$ \\
\hline & Yaşantılar Sunma & $\begin{array}{l}\text { Çocuğa yaşantılar sunmak gerek, toprağa dokunur, tiyatroya } \\
\text { götürürsünüz, sizin } 10 \text { günde anlatacağınızı, bir şairi dinlerken } \\
\text { alır bazen, bir kediye bakmakla kazanır (OÖ4). }\end{array}$ \\
\hline $\begin{array}{l}\text { Kismen } \\
\text { Kazandirilabilir }\end{array}$ & & $\begin{array}{l}\text { Dengeli ve dikkatli kullanılırsa, doğru şekilde ödüllendirilirse, } \\
\text { bazı davranışlar düzenli yaptıkça oturur, farklı yönlerle } \\
\text { desteklenirse, zamanla bunu yakalayabilir, ama tabi kısa vadede } \\
\text { beklememek gerek (PDR3). }\end{array}$ \\
\hline
\end{tabular}

Tablo 8 incelendiğinde, katılımcı öğretmenlerin çoğunluğu değerlerin ödül ceza ile kazandırılmayacağını ifade etmiş̧lerdir. Değerlerin, ödül ceza uygulamaları yerine; öğrenciye örnek olma, sinıfta farklı ögretim yöntem teknikleri kullanma ve yaşantılar sunma gibi farklı yollar ile daha iyi kazandırılabileceğine dair görüş bildirmişlerdir. Bununla birlikte bir katılımcı, ödülün dengeli ve dikkatli kullanılmasıyla, davranışların uzun vadede değer boyutuna ulaşabileceği yönünde görüş bildirmiştir.

\section{Sonuç ve Tartıșma}

\section{Sınıf Yaşamında Ödül Ceza Uygulamaları Nasıl Yer Bulduğuna Dair Sonuç ve Tartışma}

- Katılımcı öğretmenler ödülü; maddi, sembolik ve sosyal ödüller olarak farklı şekillerde vermektedirler. Cezayı daha çok mahrum bırakma şeklinde 2. Tip ceza, ya da ek görev veya sözlü uyarı gibi 1. tip ceza olarak vermektedirler. 
- Öğretmenler ödül ve cezayı, ders başarısı, aktif katılım ve daha çok istendik davranış kazandırma amacıyla kullanmaktadırlar.

- Öğretmenler ödül ve cezayı, uygun olduğunu düşündükleri ölçütlere göre vermektedirler. Ayrıca bazı öğretmenler, en başarılı olma, ilk üçe girme gibi sıralamada önde olma durumu ölçütünü, uygun bulmadıkları için kullanmaktan özellikle kaçınmaktadırlar.

Öğretmenler istendik davranış oluşturması, istenmeyen davranışların önlenmesi ve akademik başarı sağlama amacıyla, öğrencilere maddi, sosyal ve psikolojik ödüller veya cezalar vermektedir (Çolak, 2005; Gündoğdu; 2007; Sadık, 2008; Yılmaz ve Babaoğlan, 2013). Ödül ceza kullanımının ilgili araştırmalardaki amaç ve şekilleri, sınıf seviyelerinde bazı farklılıklar göstermekle beraber, bu araştırma sonuçlarıyla benzerlik göstermektedir. Erdem (2016) ve Pehlivan, Köseoğlu ve Şen (2018), yaptığ 1 araştırmalarda fiziksel ceza kullanımına rastlanmışken, bu araştırmada öğretmenlerin fiziksel ceza kullanımı bulgulanmamıştır. Bölgesel anlayış farklılıklarının (öğrenci, öğretmen ve veli açısından) buna sebep olduğu düşünülebilir.

Allen (2006), ABD' de ilköğretim öğretmenleri üzerinde yaptı̆̆ bir araştırmada, öğretmenlerin ödül ve cezayı, kendilerine en mantıklı gelen yöntemlere göre verdiklerini bulgulamıştır. Allen (2006), Aydın (2001) ve Gündoğdu (2007) ' nun yaptığı araştırma sonuçlarına göre, mesleki tecrübe, formasyon bilgisi, ilgili eğitimlere katılma gibi etkenler öğretmenlerin disiplin anlayışı ve müdahale yöntemleri arasında farklılıklar oluşturabilmektedir. $\mathrm{Bu}$ araştırmada, "ögretmenler kendilerine uygun ölçütlere göre ödül ve ceza vermektedir" bulgusunun, ilgili araştırmalarda belirtilen sebeplerden olduğu düşünülebilir. Öğretmenin sınıf için uygun olduğu ölçüte göre ödül ceza vermesi hususunda, Bloom (2016) ve Brophy ve Good (1970), sinıflarda pekiştirmeye dair ölçütlerin sınıf bazında verilmesinin doğru olmadığını belirtmiş, dönütlerin birey veya bireyler bazında belirlenmesine vurgu yapmıştır. Bu hususu, ödülün olumlu - olumsuz sonuçları tartışmalarının dışında bir konu olarak görmüş, aynı sınıfta bulunan öğrenciler olmanın aynı muameleye tabi olma anlamına gelmediğine dikkat çekmişlerdir. Alanyazında tüm öğrencilere dair beklentinin aynı olmaması gerektiği bilgisinin, bu araştırmada " bazı ögretmenler, 1. 2. 3. olma gibi siralamada önde olma ölçütünü kullanmaktan özellikle kaçınmaktadırlar " bulgusunu açılayıcı nitelikte olduğu söylenebilir.

\section{Öğretmenlerin Ödül Ceza Uygulamalarındaki Zorluklarına Yönelik Görüşlerine Dair Sonuç ve Tartışma}

- Öğretmenler ödül ve cezayı kullanırken farklı sorunlarla karşılaşmaktadırlar. Bu sorunlar; aynı uygulamaya yönelik algılarda farklılıklar olması ve nedenlerinin anlaşılmaması, takibinin zor olması ve tutarsızlıklar yaşanması, ödülün amaç haline gelmesi, farkında olmadan istenmeyen durumun pekiştirilmesi, ödül bağgmlılı̆̆ oluşması yani sürekli dönüt ihtiyacı ve ödül kullanımın kalıplaşmış yargılar olması şeklindedir.

Pekiştirme, yararlı olduğu düşünülen davranışların kalıcılığını sağlamak için yapılır. Tekrarlanan davranışın öğrenmede kalıcılığı sağlayacağı bilinen bir durumdur. Ancak, bunu kalabalık ortamlarda dengeli bir biçimde yapmak görüldüğü kadar kolay olmayabilir. Öğretmenler zamanlarının büyük bir kısmını, kuralların oturtulması ya da takibine harcasalar da, pek çok davranışın pekişmesi için yeterli zaman olmayabilir (Gordon, 2015). Bunun yanında pekiştireç almak için yalan söylemek, kıskançlık gibi istenilmeyen durumlar ortaya çıkabilir (Reeve, 2014; Yavuzer, 2015). Bir öğrenci için olumlu pekiştirme olan durum başka öğrenci için ceza olabilir ya da ceza olarak verilen durum, öğrenci tarafından ödül olarak algılanabilir (dersten çıkarmak gibi) (Bloom, 2016, s.121). Corr (2002)' nin laboratuar ortamında yaptığ 1 bir çalışmada, ödülün kişinin kendi beklentisinden az olması durumunda, ödülden memnun olmak yerine, ödülü sinir bozucu olarak karşıladığı görülmüştür. Aypay (2018) ortaokul öğrencileri üzerinde yaptığı bir araştırmada, öğrencilerin ödül bağımlılıkları arttıkça, ceza hassasiyet ve kaygılarının da artmakta olduğunu bulgulamıştır. Ödüle fazla odaklanmanın ve 
kontrolsüz verilen ödüllerin, çocuktaki keşif ve merak duygusunu azaltmak gibi önemli bir zarara yol açtı ̆̆ını belirtmiştir.

Aydın (2001), Gökçe (2002), Sadık (2008) araştırmalarında, öğrenci gözüyle demokratik ve güvenli olarak nitelendirilen sınıfların özelliklerine dair sonuçlara ulaşmıştır. Araştırma sonuçlarında "öğrenciler arasında ayrım yapmama" ve "katı kurallar koymama" en belirgin özellikler arasında bulgulanmıştır. Öğrencilere verilen ödül ve cezalarda tutarlı ve adil olma, ceza vermede dengeli olma, öğrencilerdeki güvenli ortam algısı için önemlidir (Aydın, 2001). Piaget 6-11 yaş aralığındaki çocuklarla adalet kavramı üzerinde bir araştırma yapmıştır. Çocuklar, verilen cezanın yaptığı yanlış davranışın içeriğine uygun olmasını, daha adil olarak görmüşlerdir. Çocuklar kurallara uyulmamasından dolayı verilen, yaptığı davranış ile ilgili olmayan cezaları adil görmemektedirler (odasını toplamayan bir çocuğun, sokağa çıkma hakkını elinden almak yerine, odaki bir eşyayı kullanmasının bir müddet kısıtlanması, çocuğun yaptığı yanlış davranış ile daha ilişkili olduğundan daha adil olarak algılanır). Bu durum Piaget'in cezayı onaylandığı anlamına gelmez, burada önemli olan çocuğun yaptı̆̆ 1 eylemin sosyal sonuçlarının doğal bir şekilde anlaşılmasının sağlanmasıdır (Wadsworth, 2015, s. 85-89). Bu araştırmada bulgulanan, ödül ceza uygulamalarındaki algısal farklılıklar, anlaşılmazlıklar, takip zorluğu ve tutarsızlıklar olması, istenmeyen durumların oluşması, ödülün bağımlılık oluşturması gibi sorunlar alan yazın taramaları ve ilgili araştırmalarla örtüşmektedir.

\section{Öğretmenlerin Duyuşsal Alana ve Ödül Ceza Uygulamalarına Yönelik Algılarına Dair Sonuç ve Tartışma}

- Katılımcı öğretmenlere göre, çevreye duyarlı olma, dürüstlük, israf etmeme, saygıll olma vb. gibi -istendik davranışın kalıcılı̆̆ kazandırılmaz. Ancak dikkatli kullanım ve farklı desteklerin sağlanması ile kısmen kazandırılabilir. Yine öğretmenlere göre, değerler, daha çok "örnek olma, farklı ögretim yöntem tekniklerin kullanımı veya somut yaşantılar yoluyla” ile kazandırılabilir.

Yılmaz (2018) araştırmasında değer kazanımının farklı yollardan olabileceğini bulgulamıştır. Fidan (2009) öğretmen adaylarının görüşlerine yönelik yaptığı araştırmada, değer öğretimi için en çok öne çıkan unsurun örnek olmak olduğu sonucuna ulaşmıştır. Güven (2017) ve Akcanca ve Söğmen (2018) eğitsel oyun temelli deneyimlerin istendik davranışların kazanılmasında etkili olduğunu bulgulamıştır. Bozkurt ve Sözer (2018) ilkokul öğrencileriyle yaptığı deneysel bir araştırmada öğrencilere oyun ile sorumluluk değeri kazandırılabileceği sonucuna ulaşmıştır. Türküm (1998) araştırmasında, doğaya karşı değer oluşturmak için, ödül ceza gibi dışsal uyarıcılar yerine, doğayla ilgili deneyimler yaşamanın ve yaşantılar sunmanın çok daha kalıcı olacağını ifade etmiştir. Gündoğdu (2007), Sadık (2008)' in yaptıkları araştırmalarda, ödül ve ceza kullanımının istendik davranış kazandırmada etkili olduğu görülse de; buradaki etkililik sınıf yönetimi tartışmaları boyutunda durmaktadır. Değer oluşumunun, bireyin dışsal kontrollerini zamanla içsel kontrole bırakması ve değeri uygulamada irade göstermek olduğu (Krathwohl, Bloom ve Masia, 1964) düşünülürse, ödül ceza gibi (kontrollü) dışsal uygulamaların, belli davranışların kazanılmasına bir dereceye kadar yardımcı olacağı, ancak; kalıcı olarak, bireyde bir değer oluşturamayacağ 1 yani değer boyutuna ulaşamayacağı söylenebilir. Kaufman ve O'Leary (1972) istendik davranışların kazandırılması üzerine 60 öğrenci ile 45 gün süren bir araştırma yapmıştır. Öğrencileri akademik ve davranış olarak eşit olarak gruplara ayrıldıktan sonra, iki gruba da istenen ve istenmeyen davranışları net bir şekilde açıklamış ve beklenen davranış için (öğrencilerin daha sonra kantinde harcayabilecekleri) belli miktar jeton karşıllı̆̆ belirlemiştir. Her iki grupta da aynı davranışın karşıllı̆ı aynı miktarda jetondur. Birinci gruba, gösterdiği her bir istendik davranış için belirlenen miktarda jeton -sebebi açıklanarak- verilmiş, gün içinde yaptıkları kadar jeton verilerek ödüllendirmiştir. İkinci gruba ise günlük beklenen tüm davranışın karşılığı olan jetonların tümü baştan verilmiş, aksi davranış gösterildiğinde -sebebi açıklanarak- istendik davranış için belirlenen miktarda jeton geri alınmıştır

\section{Turkish Studies - Educational Sciences}

Volume 14 Issue 3, 2019 
(cezalandırılmıştır). Ödül veya ceza uygulamasının devam ettiği zaman diliminde istendik davranışların gösterilme sıklığının artması her iki grupta da yüksek benzerlik oranında gözlenmiştir. Uygulamaya her iki grupta da ara verilmiş ve bu süre içinde, gösterilen istendik davranışların oluşma sıklığında her iki grupta da yüksek benzerlik oranında azalma görülmüştür. Uygulamaya ara verildikten sonra her bir istendik davranış için başta belirlenen jetonları kazanma ve iade etme kararını öğrencilerin kendini değerlendirerek vermeleri istenmiştir. Araştırmanın bu aşamasında da istendik davranışın görülme sıklığındaki artış her iki grupta da yüksek benzerlik oranında gözlenmiştir. Öğretmen tarafından ödül veya ceza verildiği aşamada istendik davranışların oluşma sıklığında artış gözlenmiş ancak, uygulamaya ara verilince istendik dvranışların oluşma sıklığında azalma gözlenmiş olaması, davranışın oluşmaya başladığını ancak kalıcı olmadığını göstermiştir. Öğrencilerin öz değerlendirme yaparak kendilerine ödül veya ceza vermelerinin öğretmenin ödül veya ceza vermesine göre çok daha kalıcı sonuçlar oluşturduğu gözlemlenmiştir. Bu araştırmadaki bulgular, ilgili araştırma sonuçları ve alan yazın taramaları ile paralellik göstermektedir.

Düzenin sağlanması ve istendik davranışın oluşması için, kurallanın olması gerektiği ile ilgili bir görüş birliği mevcuttur; fakat kuralların olması tek başına yeterli değildir. Kuralların uygulanabilmesi için kuralın beklentileri, sorumlulukları, normları, öğretmen ve öğrenciler açısından yeterince anlaşılır ve açık olmalıdır. Örneğin "saygılı olmak" beklentisi aslında çok soyut kalmaktadır. "Saygılı olmak nedir, hangi davranışlar saygılı olmanın göstergesidir?" gibi soruların üzerinde öğrencilerle birlikte, düşünmek, tartışmak, modellemek ve uygulamak, kurala nasıl uyulacağının anlaşılmasına yardımcı olur. Ancak, kuralın bu yönüyle, bir ders ya da bir gün sonunda tartışılarak tam olarak anlaşılması mümkün değildir, bu kazanım belki bir yıl belki daha fazla gibi uzun vadede bir beklentiyi gerektirir (Savage, 1999). Marshall (2005), istendik davranış konusunun "kural - ödül ceza" yerine, "birlikte belirlenmiş sınıf içi rutinlerin doğal sonuçları" olarak belirtmenin, daha içselleştirilmiş çözümler getireceği yönüne vurgu yapmaktadır.

\section{Öğretmen Görüşlerine Göre, Ödül- Ceza Uygulamalarının Duyuşsal Alan Açısından İstendik ve İstenmedik Sonuçlarına Dair Sonuç ve Tartışma}

- Katılımcı öğretmenlere göre, kontrollü ödüller ve bazı cezaların kullanımı öğrencide motivasyonu olumlu etkiler, ceza almak ve ödül verilen bir ortamda üst üste ödül alamamak motivasyonu olumsuz etkiler.

- Katılımc1 öğretmenlere göre, motivasyonu etkileyen unsurların uzun süre devam etmesine göre, öğrencilerde öğrenmeye karşı olumlu veya olumsuz tutum gelişir.

- Katılımc1 öğretmenlerin çoğunluğuna göre, ödül cezanın uzun süreli ve yanlış kullanımı, öğrencilerde öz denetime ciddi zarar verir ve istenmeyen değerlerin oluşmasina yol açar. Bununla birlikte bazı katılımcı öğretmenlere göre, uygun şekilde verilen ceza öğrencinin öz denetimine katk1 sunabilir.

Olumlu yaşantılar, öğrencinin bir üniteye, bir derse daha da genelde okula karşı olumlu tutum geliştirmesini sağlar. Öğrencinin motive olması ve etkin katılımı için, bireye dönük, ihtiyaca uygun yapılan pekiştirmeler ve dönütler, öğrenme deneyimlerinde çok önemli bir etkendir (Bloom, 2016). Ancak sınıflarda yapılan yanlış rekabetçi uygumalar, sürekli ödül alan öğrencilerde beğenmişlik duygusu, uzun süreli ödül alamayan öğrencilerde akademik yılgınlık oluşmasına yol açarak, motivasyonun merak ve keşif boyutuna zarar verebilmektedir (Covington, 2000). İlgili araştırmalarda ödüllendirmenin motivasyonu büyük oranda artırdığına (Cameron ve Pierce, 1994), bireye uygun olmayan ödülün bireyi motive etmediğinine (Corr, 2002), ödülün kontrolsüz kullanımının uzun vadede bakılınca içsel motivasyona zarar verdiğine (Aypay, 2018), daha çok maddi ödüllerin ve şarta bağl1 ödüllerin içsel motivasyona olumsuz etki ettiğine (Cameron ve Pierce, 1994) dair sonuçlara ulaşılmıştır. Yine cezanın motivasyonu kısmen artırdığına dair çalışmalarda (Turhan ve Yavaş, 2013) ve etkinlikten mahrum bırakma, kırıcı sözler söyleme gibi 2. Tip cezaların da motivasyona büyük 
oranda zarar verdiğine (Pehlivan, Köseoğlu ve Şen, 2018; Sürücü ve Ünal, 2018) dair bulgulara ulaşı1mıştır.

Ödül ve cezanın motivasyona etkisi ile ilgili bu araştırmalar ve alan yazın taramalarında, ödül ve ceza kullanımının genel olarak motivasyonu artırdığı ancak; kontrolsüz ve uygun olmayan ödüllerin motivasyonun içsel boyutuna zarar verdiği yönünde çeşitli bulgular ve bilgiler görülmüştür. $\mathrm{Bu}$ araştırmada, öğretmenlerin genel olarak "ödül ve (yerine göre) ceza, motivasyonu artırır" ve "ödül amaçsallaşınca merak bilgiden çok ödüle kayar, kıskançlık gibi istenmeyen durumları ortaya çıkarır" olarak ulaşılan bulguların, ödül ceza kullanımının motivasyonu genel olarak artırması ile beraber içsel motivasyona zarar vermesi yönüyle, ilgili araştırmalarla paralellik gösterdiği söylenebilir.

Krathwohl, Bloom ve Masia (1964) insanın hislerine, ilgilerine yönelik olan duyuşsal alanda, kapıların açık olması olarak ifade ettiği ilgiyi (merak), ilk basamak olarak görür. İstenilen davranışın, ilerleyen basamaklarda motive olarak, ilgi boyutundan daha kalıcı bir yapıya taşınması gerektiğini belirtir. Bu kalıcılığın sağlanması, değer verme ve irade olarak ifade edilir. İrade bir davranışı başka bir davranışa tercih etme olarak algılanabilir. $\mathrm{Bu}$ ifadeler, bireyin kendi içsel kontrolü ile sağlanabilecek bir durumu gerektirir. Marshall (2005) ödül ve ceza kullanımın getirdiği sonuçların, kısa süreli çözümlerden öteye gidemeyeceğini belirtmiştir. Bununla birlikte dışsal motivasyon kaynaklı bu vb. uygulamaların, öğrencilerin kendi sorumluluklarını kazanmaları yolunda birer engel olduğunu ifade etmiştir. Alanyazında gereğinden fazla veya yanlış kullanılan ödül ve cezaların, öğrencilerin içsel kontrolü sağlamasına engel olacağına dair görüşlerin, bu araştırmada ulaşılan "ödül ceza ile davranışın ögrencide kalıcı olmaması" ve "ödül cezanın ögrrencilerde sürekli onay ihtiyacı oluşturması" ş̧eklindeki bulguları açıklayıcı nitelikte olduğu söylenebilir.

Wadsworth (2015); bir çocuğun başkasına zarar verdiği durumlarda, zarar veren çocuğa o an ceza vermenin verilecek en uygun dönüt olduğunu ifade etmiştir. Bununla birlikte Goleman (2016), kendini kontrol etmenin o anlık görülen bir durma şeklinde değil, biliş, duyuş ve beden olarak daha sağlam temelleri olan daha kalıcı bir yapı olduğunu belirtmiştir. Bu araştırmada, katılımcı öğretmenlerin "uygun ceza, zarar verme gibi durumlarda öz denetime katkl sunar" bulgusu, alan yazın araştırmaları ile paralellik göstermemektedir. Burada tartışılan o an ceza vermenin uygun olup olmadığı değil, verilen cezanın olayı o an durdurmasının, bireyde kendini kontrol olarak anlaşılmasının doğru olmayacağı şeklinde ifade edilebilir.

Sonuç olarak;

Görüşme yapılan öğretmenler öğretmenler, ödül cezayı ders başarısı, aktif katılım ve daha çok istendik davranış kazandırma amacıyla, uygun olduklarını düşündükleri ölçütlere göre kullanmaktadırlar. Öğretmenler ödül cezayı kullanırken uygulamanın takibinin zor olması, beklentilerin net anlşılmaması, tutarsızlıklar yaşanması, ödülün amaç haline gelmesi, farkında olmadan istenmeyen durumun (kıskançlık, şımarıklık vb.) pekiştirilmesi, ödül bağımlılığı oluşmasına bağlı sürekli dönüt ihtiyacı olması vb. gibi farklı sorunlarla karşılaşmaktadırlar. Öğretmenlere göre, çevreye duyarlı olma, dürüstlük, israf etmeme, saygılı olma gibi istendik davranışın kalıcılı̆̆ olarak ifade edilen değerler, genel olarak ödül ceza kullanımı ile kazandırılmaz; daha çok "örnek olma, farklı öğretim yöntem tekniklerin kullanımı veya somut yaşantılar yoluyla" ile kazandırılabilir. Katılımcı öğretmenlere göre, kontrollü ödüller ve bazı cezaların kullanımı öğrencide motivasyonu artırmakta fakat kalıcı olmamaktadır. Kalıcı olduğu durumlarda ise sonradan farkedilen istenmeyen bazı değerlerin oluşumuna sebep olmaktadır. Ceza almak ve ödül verilen bir ortamda üst üste ödül alamamak motivasyonu olumsuz etkilemektedir. Katılımcılara göre, motivasyonu etkileyen unsurların uzun süre devam etmesiyle, öğrencilerde öğrenmeye karşı olumlu veya olumsuz tutum gelişebilir, bu sebeple ödül ve ceza uygulamalarının dikkatli, kontrollü ve planlı uygulanması gerekmektedir. Katılımcı öğretmenlerin çoğunluğuna göre, yanlış kullanım ve doğru da olsa ödül cezanın uzun süreli kullanımı, bütüncül değerlendirildiğinde öğrencilerde daha çok öz denetim boyutuna ciddi zararlar vermektedir. 
Pekiş̧irmenin öğrenme yaşantısına büyük etkisi olduğu düşünülmektedir. Ancak birey veya bireylere dönük olmayan; sınıfın tamamından aynı beklentiyi temel alan ödül ceza uygulamaları, sınıf içinde ödül alan, ödül alamayan ve ceza alan öğrenci boyutlarıyla değerlendirildiğinde, fark edilmeyen sıkıntıların oluşmasına yol açmaktatır. Aslında uygun olduğu düşünülen durumun daha sonrasında beklenmedik sonuçları oluşturabileceği görülmektedir. Ödül ceza uygulamaları kısa vadede çözüm getirdiği görülse de duyuşsal alan açısından uzun vadede kalıcı zararlar oluşturabilmektedir. Bu ve diğer nedenlerle ödül ceza uygulamalalarının, uygulanacak kişi ve kişiler, içerik, beklenti ölçütü, oluşabilecek sonuçları gibi farklı boyutlarıyla değerlendirilmesi, genel değil daha planlı ve ayrıntılı düşünülmesi gereken bir konu olduğu söylenebilir. Bununla birlikte ödül ceza uygulamaları yerine daha kalıcı olduğu düşünülen farklı yöntem ve tekniklerin kullanımının daha uzun vadede çözüm getirebileceği söylenebilir.

\section{Öneriler}

- Öğretmenler uzun süre kullandıkları ödül ceza uygulamalarının bazı yönlerini, nitel görüşme sırasında fark ettiklerini ifade etmişlerdir. Öğretmenlerin kendi uygulamalarının ayrıntılarını kendilerinin bulacakları farklı çalışmalarla buluşması faydalı olacaktır. Öğretim yılı buyunca düzenlenen eğitimlerde öğretmenlerin dinleyici olarak katıldığı seminer vb. çalışmaların yanı sıra bu şekilde farklı çalışmalara yer verilmesi faydalı olabilir.

- Öğretmenlerin yaptığını düşündükleri şey ile yaptığı şey her zaman aynı olmayabilir (Aydın, 2015). Bu çerçeve de mikro ögretim çalışmaları öğretmenler için faydalı olabilir.

- Öğretmenler, öğrencilerinden her gün kısaca notların tutulduğu bir günlük tutmalarını isteyebilir ( Bugün sinıfta beni en mutlu eden şey.............. Bugün ........ olsaydı daha mutlu olurdum). Bu günlükler aracılığı ile ödül veya cezanın öğrencilerdeki etki ve değişimini gözlemleyebilir, kendi notlarıyla karşılaştırabilir.

- Ödül ceza sürecini ve sonuçlarını araştıran çalışmaların genellikle başkalarının kullandığı ödül ceza uygulamalarını ikincil kişilerin araştırdığı çalışmalar olduğu görülmektedir. Bu konuda "Eylem Araştırması" olarak yapılacak bir çalışma literatüre önemli katkı sağlayabilir.

- Hangi ödülün hangi tepkileri oluşturduğu konusunda ödülün ya da cezanın sadece bir boyutuna yönelik derinlemesine anlamaya yardımcı olacak nitel araştırmalar yapılabilir.

- Öğretmenleri ödül ve cezaya mecbur bırakan unsurlar ve farklı yöntem tekniklerin kullanımını artırma yönünde araştırmalar yapılabilir

\section{KAYNAKÇA}

Akcanca, T. S. ve Sömen, T. (2018). Öğretmen Adaylarının Eğitsel Oyun Tasarlama ve Uygulama Durumlar1, Turkish Studies International Periodical for the Languages, Literature and History of Turkish or Turkic Volume 49-71, p. 49-71, ISSN: 1308-2140, www.turkishstudies.net, DOI Number: http://dx.doi.org/10.7827/TurkishStudies.14506, ANKARA-TURKEY

Alkan, H. B. (2007). İlköğretim Öğretmenlerinin İstenmeyen Davranışlarla Baş Etme Yöntemleri ve Okulda Şiddet. Yayınlanmamış yüksek lisans tezi, Niğde: Niğde Üniversitesi Sosyal Bilimler Enstitüsü.

Allen, D. (2006). An Investigation of Secondary Educators' Knowledge and Use of Clasroom Discipline Management Models. Unpublished master's thesis, USA: Texas Woman's University.

Aydın, B. (2001). İlköğretim Okullarında Sınıf Disiplininin Sağlanması. Yayınlanmamış doktora tezi, Bolu: Abant İzzet Baysal Üniversitesi Sosyal Bilimler Enstitüsü.

Aydın, İ. (2015). Öğretimde Denetim. Ankara: Pegem Akademi. 
Aypay, A. (2017). Ergen Gözüyle Ceza ve Etkileri. Ahi Evran Üniversitesi Kırşehir Eğitim Fakültesi Dergisi (KEFAD), 18(1), 249-268.

Aypay, A. (2018). Ortaokulda Ödül Bağımlılığı-Ceza Hassasiyeti ve Ödül Bağımlılığı-Okul Tükenmişliği Arasındaki Yordayıc İlişkiler. Eğitim ve Bilim Dergisi, 43(194), 43-59.

Bloom, B. S. (2006). Insan Nitelikleri ve Okulda Öğrenme (D. A. Özçelik, Çev.). Ankara: Pegem Akademi. (1976).

Bloom, B. S. (1956). Taxonomy of Educational Objectives: The Classification of Educational Goals. New York: David McKay Company, Inc.

Bozkurt, E. ve Sözer, A. M. (2018). Mendil Kapmaca Oyunu ile Sorumluluk Değerinin Öğretiminin Vıgnette Tekniği ile İncelenmesi, Turkish Studies International Periodical for the Languages, Literature and History of Turkish or Turkic Volume 13/27, p. 299-325, ISSN: 1308-2140, www.turkishstudies.net, DOI Number: http://dx.doi.org/10.7827/TurkishStudies. 14368, ANKARA-TURKEY

Brophy, J. E. \& Good, T. L. (1970). Teachers' Communication of Differential Expectations for Children's Classroom Performance: Some Behavioral Data. Journal of Educational Psychology, 61(5), 365-374.

Cameron, J. ve Pierce, W. D. (1994). Reinforcement, Reward and Intrinsic Motivation: A metaAnalysis. Review of Educational Research, 64(3), 363-423.

Corr, P. J. (2002). JA Gray's Reinforcement Sensitivity Theory and Frustrative Nonreward: A Theoretical Note on Expectancies in Reactions to Rewarding Stimuli. Personality and Individual Differences, 32(7), 1247-1253.

Covington, M. V. (2000). Goal Theory, Motivation, and School Achievement: An Integrative Review. Annual Review of Psychology, (51), 171-200.

Cüceloğlu, D. (2015). İnsan ve Davranışı. İstanbul: Remzi Kitapevi.

Çelik, F (2006). Türk Eğitim Sisteminde Hedefler ve Hedef Belirlemede Yeni Yöntemler. Burdur Eğitim Fakültesi Dergisi, 11, 1-15.

Çolak, M. (2005). Kütahya İli İlkögretim Okullarında Ödül ve Ceza. Yayımlanmamış yüksek lisans tezi, Manisa: Celal Bayar Üniversitesi Sosyal Bilimler Enstitüsü.

Darling, D. W. (1965). Why a Taxonomy of Affective Learning? Educational Leadership, 22(1), 473522.

Arnstine D. (1965). Taxonomy Of Educational Objectives, Handbook II: Affective Domain by David R. Krathwohl, Benjamin S. Bloom, and Bertram B. Masia. New York: David McKay Company, Inc., 1964 [Kitap Değerlendirmesi]. The Educational Forum, 29:3, 371-372.

Erdem, H. (2016). Illkokul Öğretmenlerinin İstenmeyen Öğrenci Davranışları ile Baş Etmede Kullandıkları Yöntemler. Yayınlanmamış yüksek lisans tezi, Denizli: Pamukkale Üniversitesi Eğitim Bilimleri Enstitüsü.

Fidan, N. K. (2009). Öğretmen Adaylarının Değer Öğretimine İlişkin Görüşleri. Kuramsal Eğitim ve Bilim Dergisi, 2(2), 1-18.

Gable, R. K. (1986). Instrument Development in the Affective Domain. Newyork: Springer Science Business Media. 
Gable, R. K. \& Wolf, M. B. (1993). Instrument Development in the Affective Domain: Measuring Atitudes and Values in Corporate and School Settings. Newyork: Springer Science Business Media.

Goleman, D. (2016). Duygusal Zeka (B. S. Yüksel, Çev.). İstanbul: Varlık Yayınları.

Gordon, T. (2015). Çocukta İç Disiplin mi? Dış Disiplin mi? (E. Aksay, Çev.). (1. bs.). İstanbul: Agora Kitaplığı. (1999).

Gökçe, E. (2002). İlköğretim Öğrencilerinin Görüşlerine Göre Öğretmenlerin Etkililiği. Ankara Üniversitesi Eğitim Bilimleri Fakültesi Dergisi, 35(1), 111-119.

Gömleksız, M. N. ve Kan, A. Ü. (2012). Eğitimde Duyuşsal Boyut ve Duyuşsal Öğrenme. Turkish Studies, 7(1), 1159-1177.

Gündoğdu, H. (2007). İlköğretim Okullarındaki Sinıf Öğretmenlerinin Sinıf Disiplinini Sağlamada Kullandıkları Yöntemlerin Ögrrenciler Üzerindeki Etkisi. Yayınlanmamış yüksek lisans tezi, İstanbul: Beykent Üniversitesi Sosyal Bilimler Enstitüsü.

Güven, M. (2017). Oyun Temelli Deneyimlerin Sınıf Ortamı, Öğrencilerin Davranışları, Okul Algıları ve Çatışma Dönüştürme Becerilerine Etkisi. Bartın Üniversitesi Eğitim Fakültesi Dergisi, 6(3), 1345-1366.

Karakaş, H. (2014). Etkili Sınıf Yönetimi Uygulamalarına İlişkin Öğretmen Görüşlerinin Değerlendirilmesi. Gaziantep University Journal of Social Sciences, 13(4), 1097-1119.

Karasar, N. (2008). Bilimsel Araştırma Yöntemi: Kavramlar-İlkeler-Teknikler. Ankara: Nobel Yayın Dağıtım.

Kaufman, K. F. ve O'Leary, K. D. (1972). Reward, Cost, and Self-Evaluation Procedures for Disruptive Adolescents in a Psychiatric Hospital School 1. Journal of Applied Behavior Analysis, 5(3), 293-309.

Krathwohl, D. R., Bloom, B. S., Masia and B. B. (1964). Taxonomy of Educational Objectives, Handbook 2: Affective Domain. New York: David McKay Company, Inc. Leadership, 22(1), 473.

Marshall, M. (2005). Discipline Without Stress, Punishments, or Rewards. The Clearing House: A Journal of Educational Strategies, Issues and Ideas, 79(1), 51-54.

Naz, A., Khan, W., Daraz, U., Hussain, M. and Khan, Q. (2012). The Impacts of Corporal Punishment on Students' Academic Performance/Career And Personality Development Up - To Secondary Level Education in Khyber Pakhtunkhwa Pakistan. International Journal of Business and Social Science, 2(12), 130-140.

Patton, M. Q. (2016). Nitel Araştırma ve Değerlendirme Yöntemleri (M. Bütün, S.B. Demir, Çev.). Ankara: Pegem Akademi.

Pehlivan, H., Köseoğlu, P. ve Şen, Z. (2018). Öğretmen Adaylarının Öğrenme Ortamlarında Uygulanan Ödül, Ceza ve Ayrımcılığa İlişkin Görüşleri. İlköğretim Online, 17(4).

Reeve, J. (2014). Understanding Motivation and Emotion. USA: John Wiley and Sons.

Sadık, F. (2008). İstenmeyen Davranışlarla Baş Etme Stratejilerinin Öğretmen ve Öğrenci Görüşlerine Göre İncelenmesi. İlkögretim Online, 7(2).

Savage, T. V. (1999). Teaching Self-Control Through Management and Discipline. USA: Allyn ve Bacon. 
Smith, E. E., Hoeksema, N. S., Fredrickson, B. ve Loftus R. G. (2015). Psikolojiye Giriş. (Ö. Öncül ve D. Ferhatoğlu Çev.). (3. bs.) Ankara: Arkadaş Yayınevi.

Sürücü, A. ve Ünal, A. (2018). Öğrenci Motivasyonunu Artıran ve Azaltan Öğretmen Davranışlarının İncelenmesi. OPUS-Uluslararası Toplum Araştırmaları Dergisi, 8(14), 253-295.

Şahin, S. ve Arslan C. (2014). Öğrenci ve Öğretmen Görüşlerine Göre İstenmeyen Öğrenci Davranışlarına Karşı Kullanılan Öğretmen Stratejilerinin Öğrenciler Üzerindeki Etkileri. Turkish Studies - International Periodical for the Languages, Literature and History of Turkish or Turkic Volume 9/2Winter 2014, p. 1399-1415, ISSN: 1308-2140, www.turkishstudies.net, DOI Number: http://dx.doi.org/10.7827/TurkishStudies.6103, ANKARA-TURKEY

Turhan, M. ve Yaraş, Z. (2013). Öğretmen ve Öğrencilerin Öğretmen, Disiplin, Müdür, Sinıf Kuralları, Ödül ve Ceza Kavramlarına İlişkin Metafor Algıları. Fırat Üniversitesi Sosyal Bilimler Dergisi, 23(1), 129-145.

Türküm, A. S. (1998). Çağdaş Toplumda Çevre Sorunları ve Çevre Bilinci. Çağdaş Yaşam Çağdaş İnsan. Anadolu Üniversitesi Açı Öğretim Fakültesi İlköğretim Ö̆gretmenliği Lisans Tamamlama Programı, Eskişehir, 165-181.

Tyler, R. W. (1973). Assessing Educational Achievement in the Affective Domain. NCME Measurement in Education, 4(3).

Wadsworth, B. J. (2015). Piaget'nin Duyuşsal ve Bilişsel Gelişsim Kuramı (Z. Selçuk, Çev.). Ankara: Pegem Akademi. (2003).

Yakar, A. ve Duman, B. (2017). Duyuşsal Farkındalığa Dayalı Öğretimin Akademik Başarı ve Öğretmenlik Mesleğine Yönelik Tutumlar Üzerine Etkisi. Ĕgitim Kuram ve Uygulama Araştırmaları Dergisi, 3(3), 30-47.

Yavuzer, H. (2015). Çocuk Psikolojisi (38. bs.). İstanbul: Remzi Yayınevi.

Yılmaz, B. (2018). Üniversite Ögrrencilerinin Ego Kimlik Statüleri ile Ebeveyn Otorite Stilleri ve Sosyal Değerleri Arasındaki İlişkinin İncelenmesi. Yüksek lisans tezi, İstanbul: İstanbul Aydın Üniversitesi Sosyal Bilimler Enstitüsü.

Yıldırım, A. ve Şimşek, H. (2011). Nitel Araşsırma Yöntemleri. Ankara: Seçkin Yayıncılık.

Yılmaz, F. (2011). Sinıf Öğretmenlerinin Disiplini Sağlamada Kullandıkları Ödül ve Ceza Yöntemleri (Şırnak İli Örneği). Yüksek lisans tezi, Burdur: Mehmet Akif Ersoy Üniversitesi Sosyal Bilimler Enstitüsü.

Yılmaz, F. ve Babaoğlan, E. (2013). Reward and Punishment Methods Used Elementary Teachers to Provide Classroom Discipline. Illkogretim Online, 12(1). 